\title{
Karapınar Çevresinde Yeraltı Suyu Seviye Değişimlerinin Yaratmış Olduğu Çevre Sorunları
}

\author{
Environmental Problems Caused by Ground Water Level Changes around Karapinar
}

\author{
Mutlu Yılmaz* \\ Ankara Üniversitesi, Dil ve Tarih-Coğrafya Fakültesi, Coğrafya Bölümü, Ankara
}

\begin{abstract}
Özet: Yarı kurak bir iklime sahip olan Konya Kapalı Havzası'nda son yıllardaki kuraklığa ek olarak su ihtiyacı yüksek olan tarım ürünlerinin ekiminde görülen artış, havzadaki binlerce derin sulama kuyularının sayısının çoğalmasına neden olmuştur. Bunun sonucunda; yer altı su seviyesin de alçalma ve yeni obrukların oluşumu başta olmak üzere toprakta tuzlanma, pek çok bataklık ve kaynakların kuruması, çevredeki göllerin seviyelerinin düşmesi gibi çeşitli sorunlar ortaya çıkmaktadır. Araştırma alanı olan Karapınar çevresinde son 33 yıl içinde (1977-2009) 13'ü 2006-2009 yılları arasında olmak üzere 19 çökme obruğu meydana gelmiştir. Obruk Platosu'na adını veren yüzden fazla obruk Kuaterner iklim döngülerine bağlı olarak işleyen doğal süreç sonucunda oluşmuş olsa da, yeni obrukların oluşmasında doğal süreçlerin yanında insanın önemli bir etkisi vardır. Yeraltı su akiferlerinden aşırı su çekiminin sürmesi halinde önümüzdeki yıllarda da yeni obrukların oluşması kaçınılmaz olacaktır. Ayrıca yeni oluşan obrukların ekonomik faaliyetlerin yoğun olarak yapıldığı (ulaşım, tarım vb.) ve nüfusun daha fazla olduğu güneye kayması ciddi sorunları da beraberinde getirecektir. Bu istenmeyen durumun önüne geçmek için sürdürülebilir olmayan tarımsal su yönetimi acilen terk edilmeli, bölgede yoğun olarak sulama ile yetiştirilen tarım ürünlerinin ekim alanları kısıtlanmalıdır. Ayrıca kontrollü ve yeraltı su seviyesinin daha da düşmesini engelleyecek su yönetimi planı hemen uygulanmaya konulmalıdır.
\end{abstract}

Anahtar Kelimeler: Karapınar, Yeraltı suyu seviye değişimi, Topraklarda tuzlanma, Obruk, Sulak alanlar.

Abstract: In the recent years, an increase in agricultural product planting which needs high irrigation as well as drought in Konya endoreic basin with a semiarid climate has led to an increase in the number of a thousand of deep irrigation wells in the basin. There is an excessive drawdown higher than aquifer capacity from those wells, most of which are illegal. As a result, ground water settling brings new issues such as new sinkholes, salty soil, dried moors and sources and lowering water level in the lakes nearby. Over the last 33 years (1977-2009), around Karapınar, 19 collapse sinkholes have been formed and 13 of them occurred between 2006-2009. Although more than one hundred sinkholes after which Obruk Plateau is named were formed in a natural process based on Quaternary climatic cycles, man has a great influence on the formation of new sinkholes as well as natural processes. In the near future, formation of new sinkholes will be inevitable if excessive water drawdown continues. Additionally, shift of newly formed sinkholes to the south with an intense population where economic activities take place (transportation, agriculture etc.) will bring serious problems. In order to prevent this undesirable case, unsustainable agricultural irrigation method must be quit and instead of this, a controlled water management plan to prevent low ground water levels must be practiced immediately.

Keywords: Karapınar, Groundwater level change, Salted solid, Sinkholes, Wetland area.

\section{Giriş}

Konya Kapalı Havzası (KKH) içinde yer alan Karapınar çevresinde son yıllarda yaşanan kuraklık ve değişen tarım yapısına bağlı olarak çeşitli çevre sorunları ortaya çıkmaktadır. Bölge Türkiye'de yıllık ortalama yağışın en az görüldüğü (Karapınar 283,9 mm, Konya $319.4 \mathrm{~mm}$ ) alanlardan biridir. Araştırma alanında tüm KKH'nda olduğu gibi son yıllarda su ihtiyacı çok olan tarımsal ürünlerin ekim alanlarının genişlemesi, yaşanan kuraklık gibi faktörlere bağlı olarak suya olan ihtiyaç daha da artmıştır. Bölgenin kapalı havza olması ve burada yüzeysel akışa geçen geniş bir akarsu ağının bulunmaması tarımsal sulama ve içme suyu ihtiyacının büyük ölçüde yeraltı suyundan karşılanması sonucunu doğurmaktadır. Kullanılan yeraltı suyu ise sonsuz değil ve tükenecek olan bir kaynaktır. Her geçen yıl talep artmasına bağlı olarak yeraltı akiferlerinden daha fazla su çekilmekte ve yeraltı su seviyesi düşmektedir. Bunun sonucunda da bölgede çeşitli çevre sorunları ortaya çıkmaktadır.

\footnotetext{
* İletişim: myilmaz@humanity.ankara.edu.tr
} 
Çalışma alanı son yıllarda yeraltı su seviyesi düşmesine bağlı olarak obruk oluşumlarının görüldüğü Karapınar ve çevresidir. İnceleme alanının kuzeyi Obruk Platosu içerisinde yer almaktadır (Şekil 1). Doğu'da Karapınar Ovası ve Karacadağ, güneyde Hotamış Ovası, batıda ise Bozdă̆ inceleme alanının sınırlarını oluşturmaktadır. Yapılan arazi çalışmalarında araştırma alanı içinde 13'ü 2006-2009 yılları arasında olmak üzere son 32 yılda 19 adet çökme obruğun oluştuğu tespit edilmiştir. Yeni obruk oluşumları ile yeraltı su seviyesi düşmesi arasında doğrudan bir ilişki vardır. Ayrıca bölgede göl ve bataklıklarda çekilme, tarımsal topraklarda tuzlanma, çoraklaşma ve kirlenme gibi sorunlarla karşı karşıya kalınmaktadır.

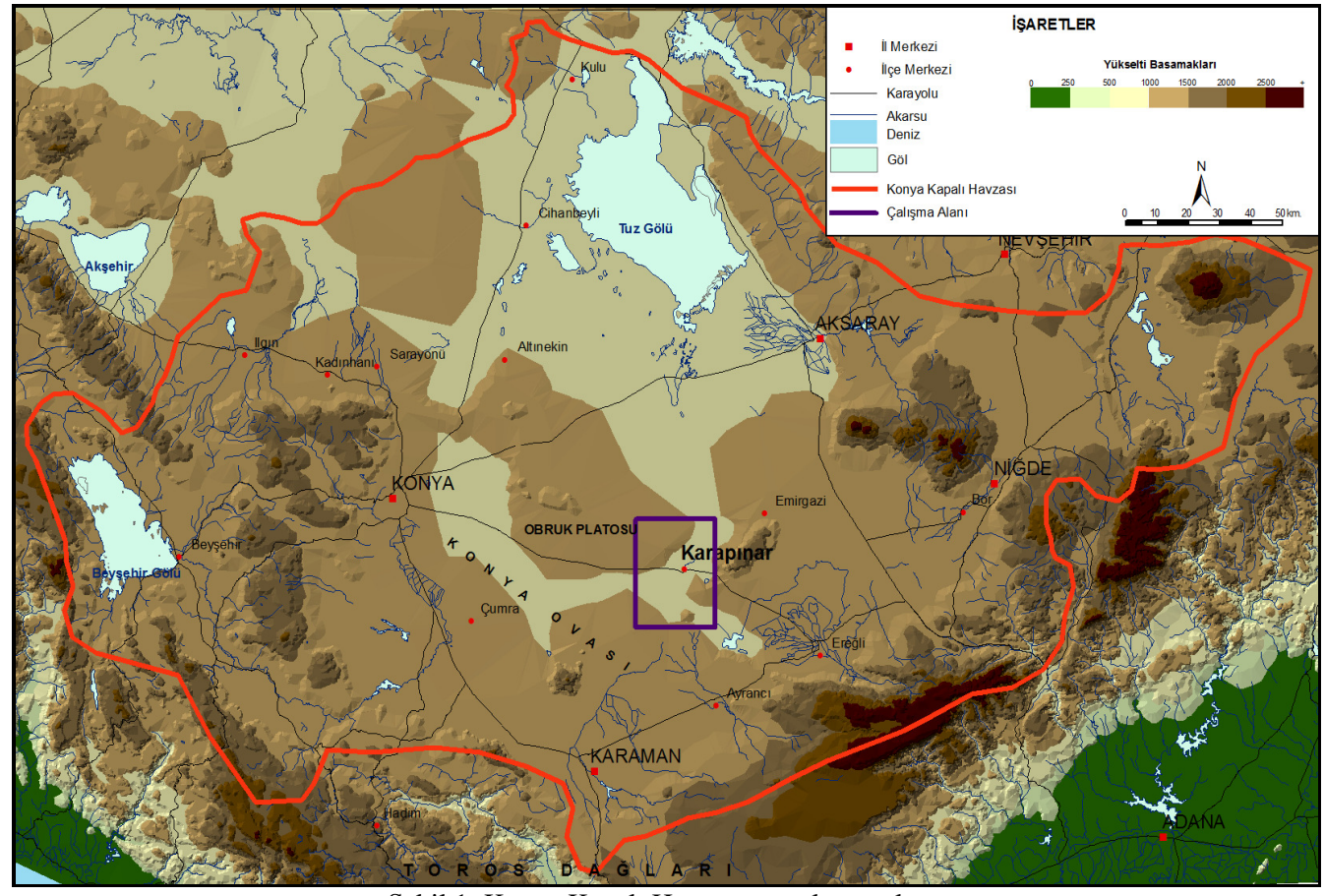

Şekil 1. Konya Kapalı Havzası ve çalışma alanı.

Konya bölgesindeki obruklar ve oluşumları ile ilgili çok sayıda araştırma yapılmıştır. Bunlar daha çok jeomorfolojik ve hidrolojik açıdan yapılan çalışmalardır (Erinç, 1960; Eroskay, 1976; Canik ve Çörekçioğlu, 1985; Çörekçioğlu, 1985; Erol, 1990; Biricik 1992; Canik ve Arıgün, 2001; Doğan ve Çiçek, 2002; Bayarı vd., 2009). Ayrıca içlerinde göl bulunan büyük obrukların doğal miras olarak koruma altına alınmasını öneren çalışmalar da bulunmaktadır (Karadoğan, 2001; Gürler ve Timur, 2007; Polat, 2008). Son yıllarda ise bölgede yeraltı suyu seviye değişimleri ve sebepleri ile ilgili çalışmalara rastlanmaktadır (Arslan ve Göçmez, 2007; Doğdu vd., 2007; Kara vd., 2008; Göçmez vd., 2008a, 2008b; Bulduk vd., 2008, Üstün vd., 2010). Bununla birlikte, bölgedeki yeraltı su seviye değişimlerinin yaratmış olduğu çevre sorunları ile ilgili çalışmalara pek rastlanmamaktadır.

\section{Yöntem}

Çalışma alanı olarak Karapınar ve çevresi ele alınmıştır. Karapınar çevresinde son yıllarda obruk oluşumu hızlanmış ve dikkat çeker boyutlara ulaşmıştır. Bölgedeki yeni obruk oluşumları ve nedenlerini incelemek araştırmanın bir boyutunu oluşturmaktadır. Bu çalışma ayrı bir yayın olarak sunulmuştur (Doğan ve Yılmaz, 2010). Ancak bölgede yapılan arazi çalışmaları sırasında yeraltı suyu seviyesi düşmesine bağlı olarak yeni obruk oluşumları dışında farklı çevre sorunları da gözlemlenmiştir. Bu gözlemler sonucunda yeraltı suyu seviye düşmesine bağlı olarak oluşan çevre sorunları ise bu makalenin konusunu oluşturmaktadır. 
$\mathrm{Bu}$ çalışmada öncelikle araştırma sahası ve KKH genelindeki daha önce yapılmış olan çalışmalar ve dokümanlar incelenmiş̧ir. Araştırmaya süresi boyunca bölgeye iki farklı dönemde arazi uygulaması yapılmışıı (Kasım 2008, Nisan 2009). Arazi çalışmaları sırasında gerekli doküman, bilgi, bulgu, fotoğraf gibi materyaller elde edilmiştir. Ayrıca yerel halktan edinilen bilgiler 1şı̆̆ında arazi çalışmalarında yeni oluşmuş olan obrukların jeomorfolojik incelemesi ve morfometrik ölçümleri yapılarak konumları ve yükseltileri GPS ile belirlenmiş ve bu obruklar hazırlanmış olan 1/100.000 ölçeğindeki haritada gösterilmiştir. Diğerlerine göre daha büyük oluşumlar olan İnoba ve Akkuyu III obrukları yakınındaki yaylalarda yaşayan yöre halkı ile konuşularak obrukların meydana geldikleri andaki durum ve gelişimi hakkında bilgi edinilmiştir.

Arazi çalışmaları sırasında sulu tarım yapılan çiftçilerle görüşülerek karşılaşmış oldukları sorunlar (su seviyesinin düşmesi, toprakta çoraklaşma, verim düşmesi, drenaj problemi) hakkında bilgi edinilmiştir. Bölgedeki önemli sulak alanlar incelenerek buralardaki değişim gözlemlenmiştir. Araştırma alanındaki çevre sorunlarına neden olduğu düşünülen yeraltı suyu seviyesi verileri Devlet Su İşleri'nden (DSİ) temin edilmiştir. Uzun yıllara ait kuyu seviye ölçümlerini kapsayan bu veriler ile grafikler oluşturulmuştur. Böylece bölgedeki yeraltı suyu seviye değişimleri net bir şekilde ortaya konmuştur. Devlet Meteoroloji İşleri Genel Müdürlüğü'nden (DMİ) elde edilen veriler ile Karapınar ve çevresinin iklim özellikleri belirlenmiştir. Ayrıca Türkiye İstatistik Kurumu'na (TÜİK) ait verilerle de Karapınar'ın nüfus özelikleri ve tarımsal yapısındaki değişimler ortaya konmuştur.

\section{Araştırma Alanının Temel Coğrafi Özelikleri}

Yarı kurak KKH, pek çok tali havzadan oluşan ve yaklaşık $53.850 \mathrm{~km}^{2}$ alan kaplayan büyük bir havzadır. Havzada çoğunluğu, güneydeki Toros Dağları'ndan kaynağını alan ve pek çoğu mevsimlik olan akarsular Konya Ovası'nda sonlanır. Tuz Gölü tali havzası ise sınırlı bir beslenme alanına sahiptir. Bu iki havza arasında bulunan Obruk Platosu düşük yağış, buharlaşma ve yeraltına olan sızma nedeniyle büyük ölçüde yüzey akışından yoksundur. KKH'nda birbirinden büyük ölçüde geçirimsiz bir formasyonla ayrılan bağımsız iki ana akifer yer alır. Bunlardan alttaki akifer PaleozoikMesozoik kayalar içerisinde, üstteki akifer ise obrukların oluşumu ve alansal dağılışını kontrol eden kireçtaşının bulunduğu Neojen formasyonu içerisindedir. Neojen akiferi soğuk $\mathrm{Ca}-\mathrm{HCO}_{3}$ tipi yeraltı suları içermekte ve bu akifere açılan 50-250 m arasındaki kuyulardan 10-70 lt/s su çekilebilmektedir (Bayarı vd., 2009).

Sahada en eski jeolojik birimler Üst Triyas-Jura dönemine aittir. Kireçtaşı, kristalize kireçtaşı, mermer, çört ve dolomitlerden oluşan Üst Triyas-Jura formasyonları İnoba Yayla'sı güneyinde ve batıdaki Bozdağ'da yüzeylenir. Bu formasyonun üzerinde kuvarsit, serpantin, şeyl ve mermerlerden oluşan Üst Kretase formasyonu yer alır. İnceleme alanında gölsel Üst Miyosen-Pliyosen formasyonu geniş alanlar kaplamaktadır. Obruk Platosundaki çok sayıda obruğun oluştuğu bu formasyon kireçtaşı, çakıltaşı, kumtaşı, marn, tüf, tüfit, çört ve sepiyolitden oluşmaktadır (Ulu, 2009a, 2009b). En genç jeolojik birimler olan Kuaterner formasyonları da çalışma sahasında Hotamış ve Karapınar ovalarında görülmektedir. Karapınar yakınlarında Miyosen volkanizması sonucunda oluşan volkanik dağlar ve maarlar yaygın olarak görülür. Obruk platosunun güneyindeki Üzecek Dağı ve Karacadağ, Meke Maarı (Tuzlası) ve Acı Göl bunlardan bazılarıdır (Sür, 1972; Somuncu,1986; Ulu, 2009a, 2009b). Sahadaki başlıca Kuaterner birimlerini, soğuk-yağışlı iklim döngülerinde (glasyal dönemlerde) KonyaEreğli ve Karapınar ovalarının bulunduğu alanları kaplamış olan Paleo-Konya Gölü'nün kalın Kuaterner depoları ve alüvyal sedimentler oluşturmaktadır (Erol, 1971; Robersts vd., 1979; Robersts vd., 1979; Bayarı vd., 2009). Bugün depresyon içinde yer alan Hotamış bataklı̆̆ı, Acıgöl, Karapınar sazlıkları Pulüvyal dönemden kalan gölün kalıntılarıdır (Gümüşcü ve Yılmaz, 2001).

Obruk Platosu ve çevresinin morfolojik çerçevesinin ortaya çıkmasında bölgede etkili olan neotektonik rejimin büyük etkisi olmuştur. Tektonizma ile rölatif olarak alçalmaya başlayan Konya grabeni kalın Kuaterner sedimentleri ile örtülürken, Obruk Platosu ise yüksekte kalmıştır. Aynı tektonik etki görülmeyen Tuzgölü alt havzası, topografik olarak KKH'nın yükseltisi en düşük alanını oluşturur. 


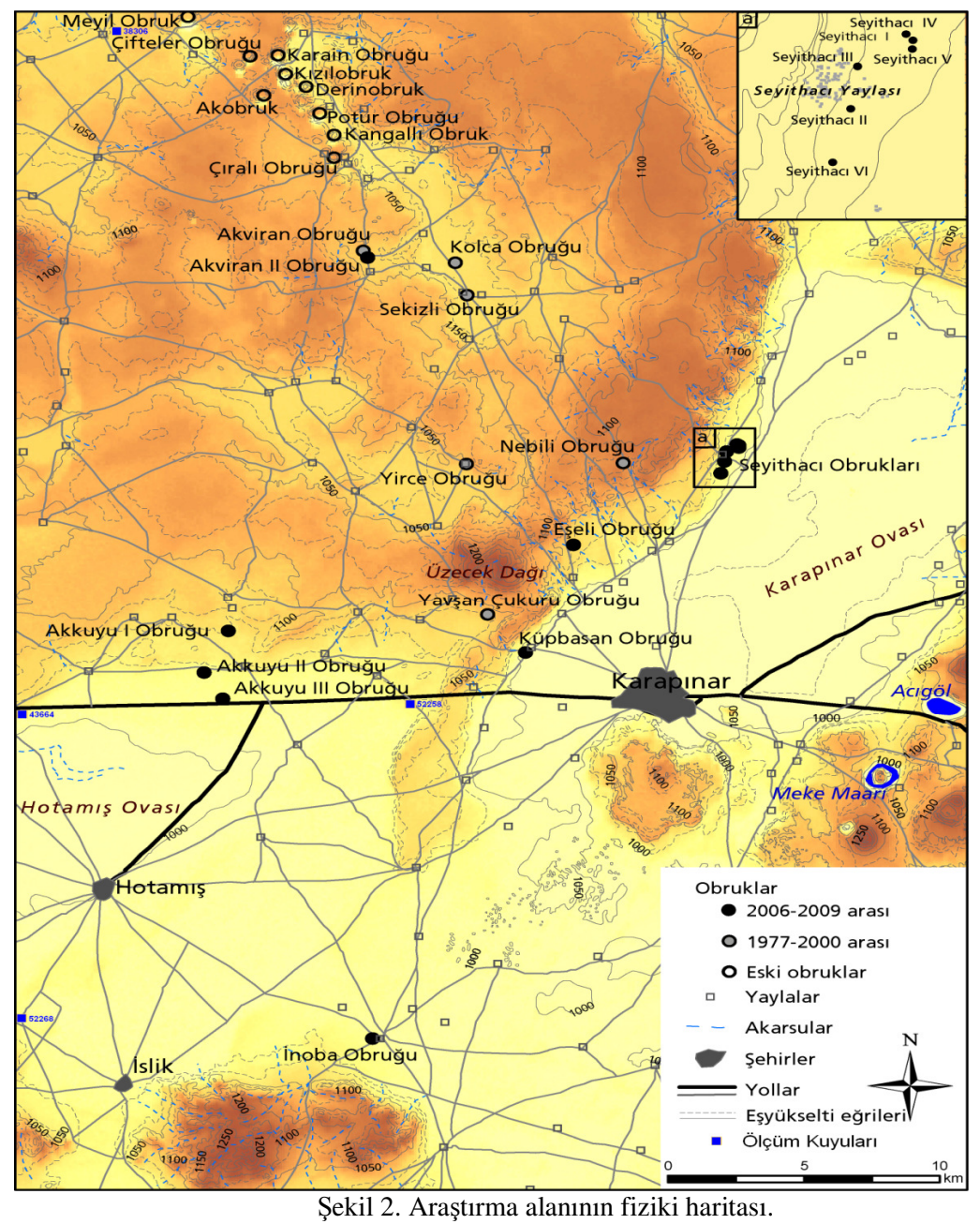

İnceleme alanını morfolojik özellikleri yönünden üç büyük üniteye ayırabiliriz. Morfolojik ünitelerden ilki olan dağlık alanlar içinde Karapınar'ın kuzeybatısında volkanik bir ünite olan Üzecek Dağı (1293 m), Osmancık Dağı (1281m) (İnoba Yayla'sı güneyi), Karacadağ'ın batı etekleri (Karapınar Ovası doğusu) belirgin olarak ortaya çıkmaktadır. Araştırma alanının kuzey ve kuzeybatısı oluşturan (ortalama $1100 \mathrm{~m}$ ) Obruk Platosu ikinci morfolojik üniteyi oluşturmaktadır. Plato içinde daha önceki dönemlerde oluşmuş çok sayıda obruk bulunmaktadır. İnceleme alanın en alçak kesimini oluşturan Karapınar ve Hotamış ovaları (ortalama 1000 m) ise üçüncü morfolojik birimdir. Bu iki ova İnoba Yayla'sı kuzeyinde dar bir eşikle birleşirler (Buldur, 2001). Bu büyük ünitelerden faklı olarak Karacadağ'ın güneybatı eteklerinde, volkanik patlamalarla oluşmuş iki morfolojik birim olan Acıgöl ve Meke Maarı bulunmaktadır (Şekil 2).

Araştırma alanındaki topraklar düz ve hafif dalgalı bir topografya olan eski göl tortuları ile volkanik temel üzerinde gelişmiştir. KKH içinde yer alan Karapınar ve Hotamış ovaların üzerinde alüvyal topraklar geniş yer kaplar. Ayrıca kolüvyal, siyerozem ve regosoller de inceleme alanında yer alan topraklardır (KHGM, 2010). Bölgedeki topraklar kireç, kil ve potas yönünden zengin, organik madde ve fosfor yönünden fakirdir (Polat, 2008). Toprakların killi bir bünyeye sahip olması tuzlanma açısından önemli riskler taşımasına neden olmaktadır. Bu topraklar üzerinde yoğun bir şekilde tarımsal faaliyetler yapılmakta olup tarım dışı alanlar ise mera olarak kullanılmaktadır. Bölgede küçükbaş hayvancılığın önemli olması geniş mera alanları sayesindedir. Karapınar ve Hotamış ovalarında tarla tarımı, Obruk Platosu'nda ise hayvancılık önemli ekonomik faaliyetlerdir. 
Karapınar' da yazları sıcak ve kurak, kışları soğuk ve çoğu zaman az yağışlı olmasından dolayı zayıf bir step (bozkır) bitki örtüsü hâkimdir. Yağış azlığı ve sıcaklıktan dolayı kurakçıl bitkiler yaygındır. Bölgede yaygın olarak geven, yavşan, deve dikeni, üzerlik, kekik, ayrık gibi bozkır bitki örtüsünün tanıtıcı bitkileri yer alır. Bu bitkiler küçükbaş hayvanlar özelliklede koyun için temel besin maddesidir. Vadi tabanlarında ise doğal olarak yetişen ahlât ve alıç ağaçlarına rastlanmaktadır.

Karapınar'da 2009 yılı TÜİK verilerine göre 31.951'i ilçe merkezi, 16.306 belde ve köylerde olmak üzere 48.257 kişi yaşamaktadır (TÜIKK, 2010a). İnceleme alanında plato üzerinde çok sayıda yayla yerleşmesi olup bunlar yaz aylarında geçici olarak kullanılmaktadır. Yöre halkı yaz aylarında hayvanlarını otlatmak için ilçe ve köylerden yaylalara giderler. Ekim ve kasım aylarında da yaylalardan tekrar dönüş başlar. Bölgedeki yerleşme dokusuna bakıldığında kırsal alanlarda (köy ve yayla) genel olarak İç Anadolu Bölgesi'ni karakterize eden ve toplu olarak bulunan kerpiç evler yer alır.

\section{Bulgular}

\subsection{Yeraltı Suyu Seviye Değişimi Nedenleri}

\subsubsection{Ikklim yeraltı suyu iliş̧kisi}

Araştırma alanı olan Karapınar'ın da içinde yer aldığı KKH'sında yazları sıcak ve kurak kışları soğuk ve yağışlı karasal iklim tipi hâkimdir. Karapınar'da ortalama yağış $283.9 \mathrm{~mm} / \mathrm{yll}$ olup, bu oran Türkiye ortalamasının $(643 \mathrm{~mm} / \mathrm{y} ı l)$ oldukça altındadır (Çizelge 1). Yıllık ortalama yağışlar bölgede yer alan diğer istasyonlardan Konya'da 319.4 mm, Ereğli'de 296.5 mm, Karaman'da ise $329.2 \mathrm{~mm}$ 'dir. Çalışma alanı ve çevresinde potansiyel evapotranspirasyonun $1300 \mathrm{~mm}$ civarında (Konya 1305 mm, Karaman, 1198 mm, Aksaray 1370 mm) olduğu göz önüne alınırsa, Kapalı havzadaki yeraltı suyu ve bunun beslendiği Toros Dağları'nın önemi ortaya çıkmaktadır.

Çizelge 1. Konya ve Karapınar'ın ortalama sıcaklık ve yağış değerleri

\begin{tabular}{lccccccccccccc}
\hline & I & II & III & IV & V & VI & VII & VIII & IX & X & XI & XII & Y1llık \\
\hline $\begin{array}{l}\text { Konya ortalama } \\
\text { sıcaklık }\left({ }^{\circ} \mathrm{C}\right)\end{array}$ & -0.3 & 1.0 & 5.4 & 10.9 & 15.6 & 20.1 & 23.5 & 22.9 & 18.6 & 12.4 & 5.7 & 1.4 & 11.4 \\
$\begin{array}{l}\text { Karapınar ortalama } \\
\text { sicaklık }\left({ }^{\circ} \mathrm{C}\right)\end{array}$ & 0.7 & 0.7 & 5.1 & 10.6 & 15.4 & 19.6 & 22.8 & 22.1 & 17.5 & 11.6 & 5.5 & 1.5 & 11.0 \\
$\begin{array}{l}\text { Konya ortalama } \\
\text { yağış miktarı }(\mathrm{mm})\end{array}$ & 33.7 & 23.8 & 26.3 & 38.6 & 41.3 & 20.9 & 7.4 & 5.2 & 11.3 & 32.8 & 37.1 & 41.0 & 319.4 \\
$\begin{array}{l}\text { Karapınar ortalama } \\
\text { yağıș miktarı }(\mathrm{mm})\end{array}$ & 29.3 & 26.6 & 27.3 & 37.1 & 38.0 & 24.8 & 4.1 & 2.3 & 8.1 & 22.2 & 27.2 & 36.9 & 283.9 \\
\hline
\end{tabular}

Karapınar'da en fazla yağış ilkbaharda (\%38), sonra sırasıyla kış (\% 36), sonbahar (\%17) ve yaz (\%9) aylarında düşmektedir. Yağışın az olduğu dönem şiddetli buharlaşmanın da gerçekleştiği yaz aylarıdır. En fazla yağış nisan $(37.1 \mathrm{~mm})$ ve mayıs $(38 \mathrm{~mm})$ aylarında düşmektedir. En az yağış ise ağustos $(2.3 \mathrm{~mm})$ ayında düşmektedir. Bu durum özellikle bitki yetişme dönemi olan yaz aylarında sulamayı zorunlu kılmaktadır. Çünkü bölgede yağışların ancak \%30-35'i bitki yetişme döneminde düşmektedir (Toprak vd., 2008). Bu özellikler bölgenin yağış bakımından yarı karasal olduğunu gösterir.

Yıllık ortalama sıcaklığın $11^{\circ} \mathrm{C}$ olduğu Karapınar'da en soğuk ay ortalama değeri ile $-0.4^{\circ} \mathrm{C}$ ile ocak ve en sıcak ay ise $22,6^{\circ} \mathrm{C}$ ile temmuz ayıdır (Çizelge 1). Haziran, temmuz ve ağustos ayları ortalama sıcaklıkların fazla olduğu aylardır. Özellikle bu dönemde tarımsal ürünlerde su ihtiyacı çok büyük olmaktadır.

Son yıllarda dünyada hissedilen küresel iklim değişikliği ve mevsim değişiklikleri Türkiye'yi de etkilemiştir. Birçok bölgemizde özellikle de İç Anadolu ve Ege Bölgesi’nde yağış azlığı (kuraklık) ve aşırı su tüketimi (plansız ve izinsiz) yüzey suları ve yeraltı suyu açısından sorunlara yol açmaktadır. Doğdu vd. (2007) yapmış oldukları çalışmada KKH'nda genel olarak 1960'lı yılların başından 1980'li yılların başına kadar yağışlı dönemin hâkim olduğu, 1980'li yılların başından günümüze kadar süren 
dönemde ise kurak bir dönemin yaşandığını belirtmektedirler. Karapınar'da yağışın yıllar arasındaki değişimini incelediğimizde bu sonuç çok net olarak görülmektedir (Şekil 3). Bölgeye 1980 sonrası dönemde 12 yıl yıllık yağış ortalamasının üzerinde, 16 yıl ise altında yağış düşmüştür. Bölgede gerçekleştiği düşünülen bu 25-30 yıllık kurak dönemin yeraltı suyu seviyelerine olumsuz etkisi önemli boyutlardadır. İklimsel değişikliklerin yeraltı su seviyelerini önemli ölçüde tetiklediği yapılan çalışmalarda ortaya çıkmıştır. Doğdu vd., (2007) yapmış oldukları çalışmada 1980'li yıllardan itibaren havzada ölçüm yapılan kuyularda yeraltı suyu seviye düşmelerini Karapınar'da 0.7 m/yıl olduğunu belirtmektedir. Göçmez vd. (2008a) yapmış olduğu çalışmada yeraltı su seviyesindeki alçalmada iklim etkisinin \%60 seviyesinde olduğunu belirtmektedir. Ayrıca Türkeş vd. yapmış oldukları çalışmalarda (Türkeş ve Erlat, 2005, Türkeş, vd., 2009) Kuzey Atlantik Salınımı ve İç Anadolu Bölgesi'ndeki yağışlar hakkında negatif bir korelasyon olduğunu belirtmektedir.

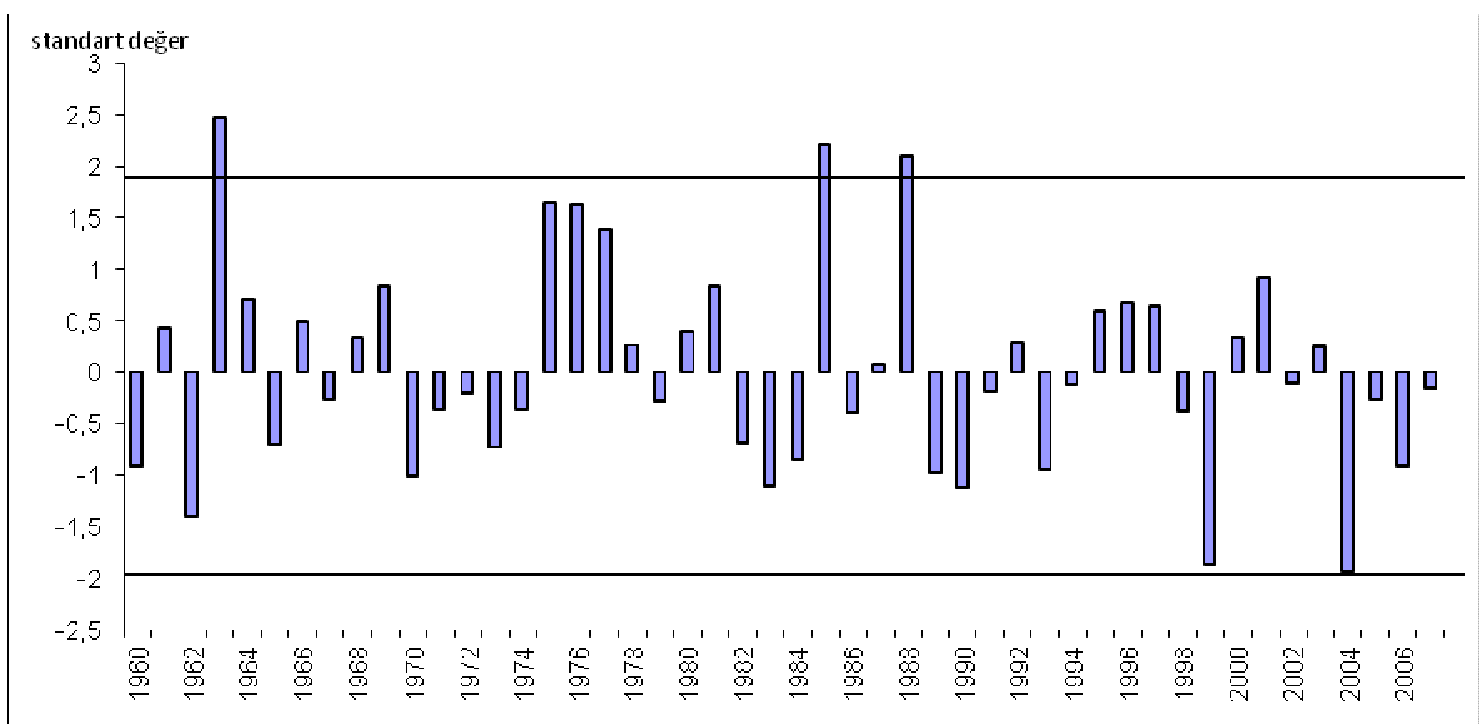

Şekil 3. Karapınar' da yağışın yıllar arasındaki değişimi (1960-2007).

Kaynak: DMİ Gen. Müd. İstatistikleri

Karapınar çevresinin kurak bir iklime sahip olması toprakların tuzlanmasına uygun bir koşul hazırlamaktadır. Bölgede yetersiz yağış nedeniyle topraktan yıkanıp uzaklaşmayan tuzlar, aşırı ve bilinçsiz sulama nedeniyle önemli bir çevre sorunu yaratmaktadır. Ayrıca yetersiz yağı̧s nedeniyle akarsu ve göl havzaları beslenememekte ve göllerin seviyelerinde düşmeler gözlenmektedir.

\subsubsection{Tarım yeraltı suyu ilişkisi}

Tarım, araştırma alanında en önemli ekonomik faaliyet koludur. Karapınar ve çevresi genel olarak geniş ova ve platolardan oluşmaktadır. Bu morfolojik ünitelerde de kuru tarım özelliklede tahıl tarımı yoğun bir şekilde yapılmaktadır.

Karapınar'da 2009 yılı verilerine göre 1.383 .810 dekar arazi tarım alanı olarak kullanılmaktadır. Bunun 912.215 dekarı ekilen alan, 458.360 dekarı nadas, 11.210 dekarı sebze ve 2.025 dekarı ise meyve bahçelerine ayrılmış durumdadır (TÜIK, 2010b).

Karapınar'da tarım alanlarının \%75.5'inde (688.466 dekar) tahıl tarım yapılmaktadır (Çizelge 2). Tahıl tarımı içinde ilk sırada buğday, sonra sırasıyla arpa, mısır ve çavdar yer alır. Endüstri bitkileri ekim alanlarının \%11.5'ni (104.809 dekar) oluşturmaktadır. Endüstri bitkileri içinde ekim alanları son yıllarda genişleyen şeker pancarı (103.809 dekar) oldukça büyük bir alan kaplar. Yıllık su tüketimi $825 \mathrm{~mm}$ olan şeker pancarı Karapınar ve Hotamış ovalarında yoğun bir şekilde sulama ile yetiştirilmektedir. Bu ürün bölgede yetişme döneminde 7-9 defa sulanmaktadır. Tarım alanlarının \%9.1'inde (83.100 dekar) yem bitkileri yetiştirilmektedir. Yem bitkileri içerisinde ise y1llık olarak 
$1200 \mathrm{~mm}$ su isteyen yonca (52.500 dekar) geniş bir ekim alanına sahiptir. Sonra sırasıyla yağlı tohumlar, baklagiller ve yumrulu bitkilerin ekimi yapılmaktadır. Yağlı tohumlar içinde ayçiçeği (20.585 dekar), baklagiller içinde nohut, yumrulu bitkiler içinde patates ön planda gelmektedir.

Çizelge 2. Karapınar İlçesi'ndeki tarla tarımı alanı (2009)

\begin{tabular}{ccc}
\hline Tarla tarımı & Ekim Alanı (dekar) & $\%$ \\
\hline Tahıllar & 688.466 & 75.5 \\
Endüstri Bitkileri & 104.809 & 11.5 \\
Yem Bitkileri & 83.100 & 9.1 \\
Yağlı Tohumlar & 22.785 & 2.5 \\
Baklagiller & 10500 & 1.1 \\
Yumrulu Bitkiler & 2555 & 0.3 \\
Toplam & 912.255 & 100 \\
\hline
\end{tabular}

Kaynak: TÜİK, Tarım istatistiklerì

Konya havzasında sulu tarım yapılan bitkilerin su tüketim değerleri incelendiğinde bölgedeki yă̆ış-su kullanım dengesi çarpıcı bir şekilde ortaya çıkmaktadır. Çünkü bölgede yetiştirilen pek çok bitkinin su yetişebilmesi için gerekli olan su tüketimleri yıllık yağış ortalamasının oldukça üzerindedir. Örneğin, şeker pancarının yetişebilmesi için ortalama $825 \mathrm{~mm}$ yă̆ışa ihtiyaç vardır. Ancak Karapınar' da yıllık yağış $(283.9 \mathrm{~mm})$ bu değerin çok altındadır. Ayrıca Karapınar'a düşen mevcut yağışın büyük bir bölümüde ilkbahar ve kış aylarında düşmektedir. Şekerpancarının gelişme dönemi olan yaz aylarında bölgedeki yağış son derece az buharlaşma ise oldukça yüksek seviyededir. $\mathrm{Bu}$ durumda bölgede şekerpancarı ancak sulama yapılarak yetiştirilebilmektedir. Bu bitkinin yetişme döneminde ihtiyacı olan ve yağış dışında sulama yapılarak karşılanan suya net su ihtiyacı denir. Bu bölgede şekerpancarı yetişebilmesi için gerekli net su ihtiyacı ise $705 \mathrm{~mm}$ 'dir (Çizelge 3). Ayrı durumu yetiştirilen diğer tarımsal ürünlerde de görmek mümkündür. Örneğin bölgede mısır yetiştirebilmek için $630 \mathrm{~mm}$, ayçiçeği için $500 \mathrm{~mm}$ net su ihtiyacına gerek vardır.

Çizelge 3. Konya havzasında sulu tarım yapılan bitkilerin su tüketimi ve net su ihtiyaçları.

\begin{tabular}{llllllllll}
\hline & Buğday & Arpa & Ş.pancarı & K.fasülye & Mısır & Patates & Ayçiçeği & Sebze & Yonca \\
\hline Su tüketimi $(\mathrm{mm})$ & 441 & 420 & 825 & 535 & 685 & 605 & 615 & 750 & 1200 \\
Net su ihtiyacı $(\mathrm{mm})$ & 400 & 350 & 705 & 480 & 630 & 540 & 500 & 705 & 1000 \\
\hline
\end{tabular}

Burada dikkati çeken konu özellikle sulama ihtiyacı yoğun olan bazı tarımsal ürünlerin ekim alanlarındaki genişlemesidir. Örneğin, şekerpancarı ekim alanlarını incelediğimizde bu genişleme açık bir şekilde gözlenmektedir. Karapınar'da 1991 yılında 29.630 dekar alanda şekerpancarı ekimi yapılmıştır. Ürünün ekim alanları 2005 yılında 56.521 dekara, 2009 yılında ise 103.809 dekara yükselmiştir (Çizelge 4). Yani aradan geçen 18 yılda şekerpancarı ekim alanları \%350 oranında artmıștır.

Karapınar'da mısır 1999 yılında 880 dekar alanda ekilmiştir. Daha önceki yıllarda ilçede mısır ekim alanlarına ait bir istatistik veriye rastlanamamıştır. Bu da sulu tarım alanlarının artmasına bağlı olarak yöre çiftçisi tarafından daha fazla gelir getiren bu tür bitkilerin yetiştirilmeye başlandığını göstermektedir. İlçede mısır ekim alanları 2005 yılına gelindiğinde büyük bir artışla 54.200 dekar, 2009 yılında ise 69.648 dekara ulaşmış̧ır.

Aynı durumu ayçiçeğinde de görmek mümkündür. Ayçiçeği Karapınar'da ilk defa 2004 yılında 70 dekar alanda ekilmiştir. Daha sonraki yıllarda ayçiçeği ekim alanları her sene genişleyerek 2009 yılında 20.585 dekara ulaşmıştır. Aradan geçen 5 yıllık süreçte ayçiçeği ekim alanlarındaki genişleme muazzam seviyededir.

Karapınar'da 2000 yılına kadar hiç ekimi yapılmayan mısır, ayçiçeği gibi tarımsal ürünler ile bu yıl öncesinde daha sınırlı bir alanda ekimi yapılan şekerpancarı ekim alanları son yıllarda çok büyük oranda artmıştır. Su isteği yüksek olan bu tür bitkilerin ekim alanlarındaki genişlemeye bağlı olarak yeraltı su seviyesinde bu yıllarda çok hızlı bir şekilde düşmüştür. $\mathrm{Bu}$ da bize bu ürünlerin ekimi ile su seviyesi arasındaki ilişkiyi açık bir şekilde göstermektedir. 
Çizelge 4. Karapınar İlçesi’nde bazı tarımsal ürünlerin ekim alanları (1991-2009).

\begin{tabular}{lrrrrrrrr}
\hline Tarım alanı / yıl & 1991 & 1995 & 2000 & 2005 & 2006 & 2007 & 2008 & 2009 \\
\hline Şekerpancarı (dekar) & 29.630 & 20.020 & 55.910 & 49.780 & 56.521 & 69.718 & 97.378 & 103.809 \\
Mısır (dekar) & - & - & 1.210 & 54.200 & 40.431 & 56.009 & 71.083 & 69.648 \\
Ayçiçeği (dekar) & - & - & - & 100 & 788 & 4.625 & 20.736 & 20.585 \\
\hline
\end{tabular}

Araştırma alanında son yıllarda su isteği çok olan tarımsal ürünler yetiştirilmesi Karapınar ölçeğinde tüm KKH için geçerli bir durumdur. Bu da havzadaki yeraltı su seviyesindeki düşmeyi açık bir şekilde tetiklemektedir. KKH toplam emniyetli yeraltı suyu rezervi yıllık yaklaşık 1.8 milyar $\mathrm{m}^{3}$ iken çekilen yıllık su miktarı su miktarı 2.6 milyar $\mathrm{m}^{3}$ tür. $\mathrm{Bu}$ durum havzada yaşanan çevre sorunlarının en önemli nedeni olarak karşımıza çıkmaktadır.

Araştırma alanındaki en önemli tehditlerden biri bölgedeki tarımsal sulamanın sürdürülebilir olmamasıdır. Türkiye'de tatlı su kaynaklarının \%72'si tarım sektöründe kullanılmaktadır. Oysa bu oran KKH'nda \% 88'i bulmaktadır (Anonim, 2010). Bölgede yüzeysel akışa geçen önemli akarsuların olmaması yeteri kadar baraj ve sulama göleti bulunmaması nedeniyle tarımsal amaçlı olan suyun çok büyük bir kısmı yeraltı akiferlerinden karşılanması sonucunu doğurmaktadır.

Karapınar ve çevresinde tarımsal yapıda meydana gelen bu değişimin ilerleyen yıllarda göç başta olmak üzere çok ciddi sosyo-ekonomik sonuçları olacaktır. İçinde bulunduğumuz dönemde sulu tarım ile çiftçilerin daha fazla gelir elde ettikleri bir gerçektir. Ancak bölgede yaşanan kuraklık ve yeraltından yıllık beslenme miktarı üzerinde aşırı su çekilmesi, her geçen yıl çiftçilerin suya ulaşmasını zorlaştıracaktır. Buna bir de çiftçinin sulu tarım tekniklerini yeterli ölçüde bilmemesi ve teknolojiyi kullanamaması, yetersiz drenaj gibi faktörlerde eklenince tarımsal toprakların özelliklerini kaybetmesi kaçınmazdır. Nitekim ovada bu durum gözlemlenmeye başlamıştır. Böyle bir durumda da bölgede yaşayan çiftçiler zor durumda kalacaklar ve sulu tarım alanlarında verim düşmesi, toprakta tuzlanma gibi sonuçlarla karşılaşacaklardır.

\subsection{Yeraltı Suyu Seviye Değiş̧imleri}

Yeraltı suyu seviye değişmeleri çeşitli nedenlerle olmaktadır. Bunlardan meteorolojik, hidrolojik ve jeolojik nedenler seviye değişimlerini yaratan doğal faktörlerdir. Özellikle tarımsal sulama veya içme suyu ihtiyacı için yeraltından su çekilmesi ise beşeri faktör olarak görülmektedir.

Yağışlar ile yeraltı suları arasında doğrudan bir ilişi bulunur. Genellikle yıl içindeki yağışların fazla olduğu kış ve bahar aylarında yeraltı suyu seviyeleri artarken, yağışların çok az olduğu yaz aylarında ise düşmektedir. Son yıllarda KKH'sında genelinde su isteği çok olan tarım bitkilerini (şeker pancarı, mısır, ayçiçeği, sebze, yonca vb.) yetiştirmek için büyük çoğunluğu kaçak olan binlerce (yaklaşık 94.000) kuyudan aşırı su çekilmesi ve artan kuraklık sonucunda, su tablasında önemli bir alçalma meydana gelmiştir (Doğdu vd., 2007; Bulduk vd., 2008; Göçmez vd., 2008b; İşçioğlu, 2008; Bayarı vd., 2009).

Havza genelinde sulu tarım alanlarının genişlemesine bağlı olarak açılan kuyu sayısı her geçen gün daha da artmaktadır. Plansız ve bilinçsizce açılan bu sulama kuyuları akiferlerin özelliklerinin bozulmasına, temiz ve kirli akiferlerin sularının birbirine karışmasına ve bununu sonucu olarak da su kirliliğine neden olmaktadır.

Bölgede yapılan çalışmalarda yeraltı suyu seviyesindeki gerilemeler açıkça ortaya çıkmaktadır. Konya, Çumra, Karapınar, Ereğli, Sultanhanı, Obruk ovaları $615 \mathrm{hm}^{3} / \mathrm{y} 1 \mathrm{l}$ emniyetli su rezervine sahiptir. Ancak Neojen akiferinden çekilen suyun $267 \mathrm{hm}^{3} / y 1 l$ akifer veriminin üzerindedir (Göçmez vd., 2008a). Bayarı vd. (2009) yapmış olduğu araştırmada Obruk Paltosu'nun da araştırma alanın kuzeyinde yer alan Çıralı Obruğu'ndaki göl seviyesinin 1970 yılların sonlarına göre 2003 yılı ağustos ayında 30 m düştüğünü hesaplamıştır. Doğdu vd. (2007) yapmış oldukları araştırmada 19822007 yılları arasında yeraltı suyunun Konya Ovası'nda $\sim 0.2-0.9$ m/y1l ve Karapınar'da $\sim 0.7$ m/yıl düştüğünü hesaplamıştır. 
Havza genelinde yeraltı suyu seviyesindeki alçalmaları, bölgede 1980 yılından itibaren etkili olan kurak dönem de desteklemektedir (Doğdu vd., 2007). Göçmez vd. (2008a) yeraltı suyundaki değişimin Konya'da \%60, Karapınar' da \% 40'nın iklimsel değişkenlerle geri kalan aşırı su çekimi ile ilgili olduğunu söylemektedir. Bu süreç havzadaki yeraltı suyu seviyesinin düşmesine ve bazı akiferlerin özelliğini kaybetmesine neden olmuştur. Buna bağlı olarak da pek çok bataklık ve kaynak kurumuştur. Ayrıca araştırma alanında yer alan göllerin de seviyeleri alçalmıştır.

Araştırma alanı içerisinde yer alan kuyularda yapılan ölçümlerde yeraltı su seviyesindeki bu düşüşü rahat bir şekilde gözlemlenmektedir. Karapınar yerleşmesinin $10 \mathrm{~km}$. kadar batısında yer alan Gülfet Yayla'sında yer alan kuyuda (kuyu no 52258 veya 200) 40 yıllık bir döneme ait veri bulunmaktadır. 52258 nolu kuyuda 1969 yılında -17.4 m olan yeraltı su seviyesi 2008 yılında -41.3 m’ye gerilemiştir. Kuyuda yapılan ölçümlere göre yer altı suyu seviyesi 1990 yılına kadar çok belirgin bir düşme trendi içinde değildir. 1969-1990 yılları arasında geçen 22 senede yeraltı su seviyesi sadece $1.9 \mathrm{~m}$ gerilemiştir.1999 yılından sonra yeraltı su seviyesindeki gerileme oldukça belirgindir. $\mathrm{Bu}$ dönemin sonu olan 2000 yılına gelindiğinde yer altı su seviyesi -27 m'ye gerilemiştir. Ancak yer altı su seviyesindeki asıl gerileme 2000 yılından sonraki dönemde olmuştur. 2000 yılında $-27 \mathrm{~m}$ olan su seviyesi, 2002 yılından $-29.2 \mathrm{~m}, 2005$ y1lında $-31,5 \mathrm{~m}, 2008$ y1lında ise -41.3 m'ye gerilemiştir (Şekil 4). Bölgede yeraltı su seviyeleri son yıllarda yıl içerisinde de önemli ölçüde değişmektedir. Bu değişim özellikle 2000 y1lından sonra çok belirgin bir hal almıştır. Kuyularda y1l içerisinde ocak, nisan, temmuz ve ekim aylarında ölçüm yapılmaktadır. Örneğin 2008 yılı ocak ayında Gülfet Yayla kuyusundaki su seviyesi -37.4 m'dir. Su seviyesi nisan ayında $-36.9 \mathrm{~m}$, temmuz ayında $-40 \mathrm{~m}$, ekim ayında ise -41.1 m’ye gerilemiştir. Kuyuda yıl içindeki seviye gerilemesi 3.7 metreyi bulmuştur (Şekil 4).

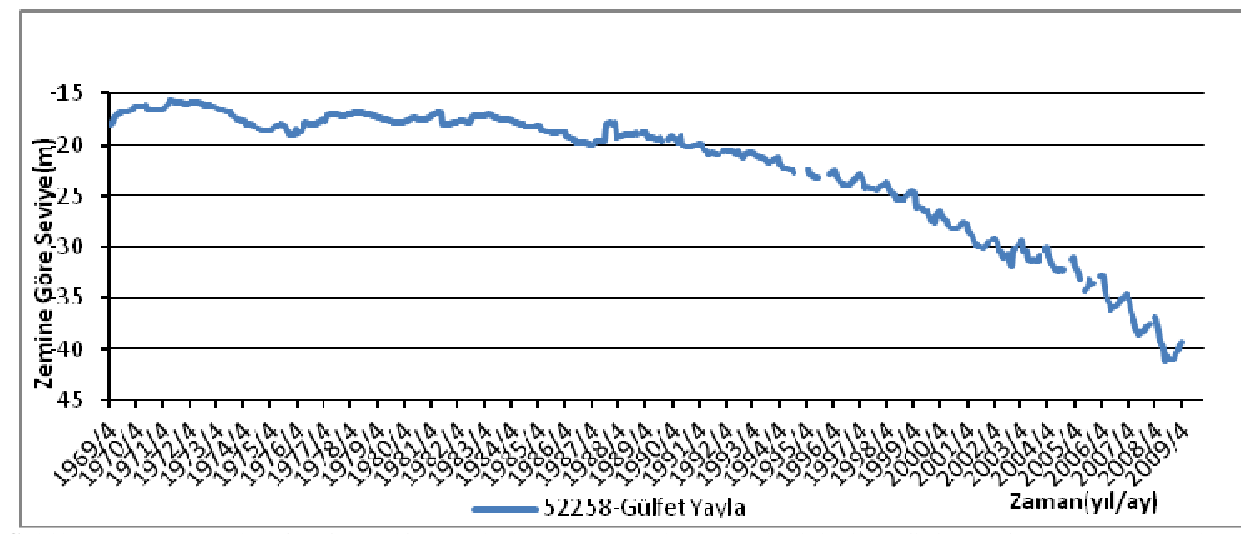

Şekil 4. Karapınar'da (52258 Gülfet yayla kuyusu) yeraltı suyu değişimi grafiği (1969-2008). Kaynak: DSİ, 2010)

Araştırma alanı içerisinde yer alan bir başka kuyu olan Eğilmez kuyusunda (kuyu no 52268) da yeraltı su seviyelerindeki değişim konusunda benzer durum gözlenmektedir. Kuyuda yeraltı suyu seviyesi ölçümün yapıldığı 1974 yılında -15.1 m iken 2008 yılında -37.6 m’ye gerilemiştir. Aradan geçen 35 yıllık dönemde yeraltı suyu seviyesi 22,5 m düşmüştür (Şekil 5). Burada da yer altı suyu seviyesindeki gerileme büyük ölçüde 2000 yılından sonra hız kazanmıştır. Yeraltı su seviyesindeki düşme trendi tıpkı Gülfet Yayla kuyusunda olduğu gibidir. 


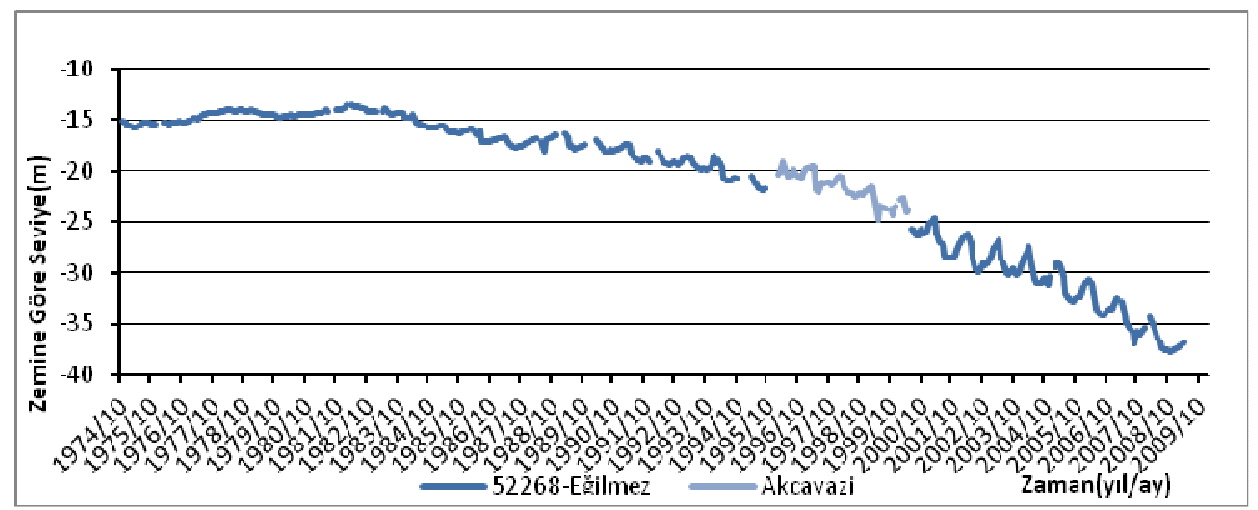

Şekil 5. Karapınar'da (52268-Eğilmez-Akçayazı kuyuları) yeraltı suyu değişimi grafiği (1974-2008).

Not: 1996-2000 yılları arasında Eğilmez kuyusunda ölçüm yapılmadığı için yakın olan 43664 nolu Akçayazı kuyusunun verileri kullanılmıştır, Kaynak: (DSİ, 2010)

Karapınar ve Hotamış ovalarında yoğun olarak sulu tarım yapılan alanlarda bunlara benzer birçok kuyuda DSİ ve araştırmacılar tarafından ölçümler yapılmıştır. Bu ölçümlerin hemen hemen hepsinde yeraltı su seviyesindeki gerilemeyi gözlemlemek mümkündür (Doğdu, 2007; Göçmez, 2008a, 2008b; Bozyiğit ve Tapur, 2009). Bu kuyulara göre daha kuzeyde olan ve Obruk Platosu üzerinde yer alan Yenikent ( kuyu no 38036) kuyusunda ise 1996-2008 yılları arasında bir ölçüm değeri bulunmaktadır. Ölçüm kuyusu Meyil obruğunun batısında 1046 m de yer almaktadır. Kuyu platodaki yeraltı suyu değişimini göstermesi açısından önemlidir. Kuyudaki yeraltı su seviyesi ölçümün başladığı 1996 yılı ekim ayında -67 m'dir. Kuyudaki su seviyesi 2008 yılı temmuz ayında ise -82.6 m'ye gerilemiştir. Ölçümün yapılan 13 yıllık dönemde su seviyesi 15.6 m düşmüştür (Şekil 6). Bu veriler hem ovada hem de platoda yeraltı suyunun dramatik bir şekilde azaldığını göstermektedir.

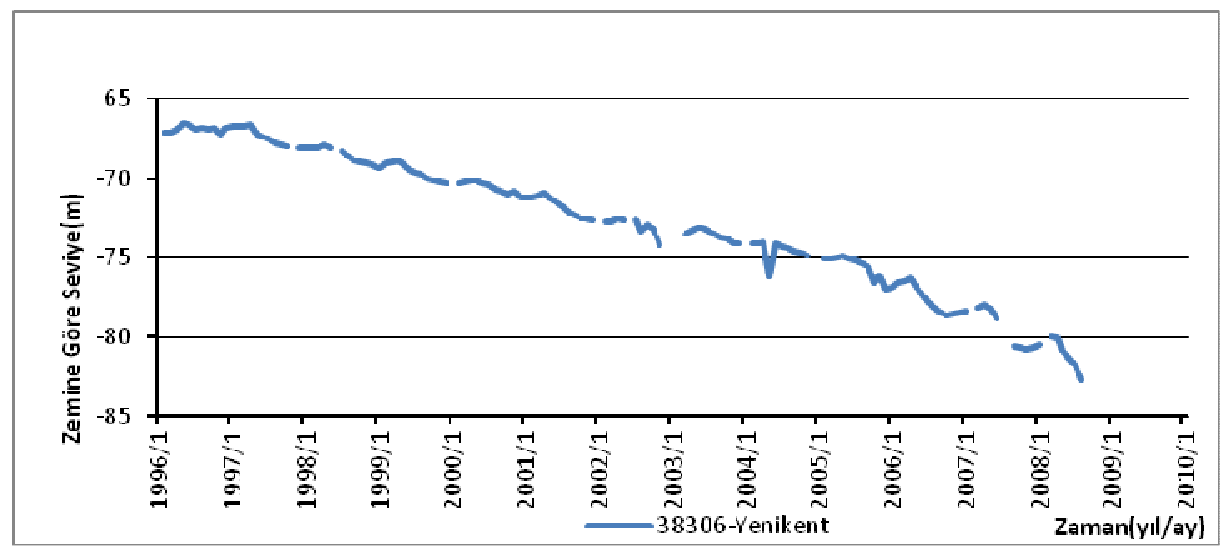

Şekil 6. Karapınar'da (38306 Yenikent kuyusu) yeraltı suyu değişimi grafiği (1996-2008). Kaynak: (DSİ, 2010)

\subsection{Yeraltı Suyu Seviyesindeki Düşmelere Bağlı Olarak Oluşan Çevre Sorunları}

\subsubsection{Yeni obruk oluşumu}

Karapınar ve çevresinde yaşayan halk, yayınlar ve resmi kuruluşlardan elde edilen bilgilere göre, oluşum zamanları bilinen veya en azından yeni oluştuğu fark edilmiş olan obrukların en eskisi 1977 y1lına aittir. Bu tarihten itibaren geçen 32 yıl içerisinde toplam 19 adet çökme sonucu olan obruk oluşmuştur (Şekil 2, Çizelge 5). Çökme obrukları karstik yeraltı boşlukları ya da mağara tavanları üzerindeki yükü taşıyamayacak duruma gelmesi sonucu aniden oluşan dairevi görünüşü, dik yamaçlara sahip çukurlardır (Erinç, 2001; Lowe and Waltham, 2002; Doğan, 2004). Bu obruklardan 6 
tanesi 2000 yılı öncesinde oluşmuştur. Araştırma alanında 2006-2008 yılları arasında ise 13 obruk oluşmuştur (Doğan ve Yılmaz, 2010). Yayla yerleşmeleri ve yolların kenarında veya yalnızca birkaç yüz metre uzağında oluşan obruklar, oluştukları tarihlerde halkta büyük tedirginlik yaratmış fakat geçen zaman içerisinde korkular büyük ölçüde unutulmuştur.

Çizelge 5. Karapınar çevresinde yeni oluşan obrukların morfometrik özelikleri (1977-2009).

\begin{tabular}{llcccc}
\hline Obruk İsmi & Oluştuğu Y1l & $\begin{array}{c}\text { Yükseklik } \\
(\mathrm{m})\end{array}$ & Çap (m) & $\begin{array}{c}\text { Derinlik } \\
(\mathrm{m})\end{array}$ & Göl \\
\hline Akviran Obruğu & 1977 & 1048 & 19,3 & 78 & + \\
Nebili Obruğu & 1983 & 1090 & 18,5 & 23 & - \\
Sekizli Obruğu & 1983 & 1033 & 16,7 & 3,30 & - \\
Yirce Obruğu & 1985 & 1065 & 45 & 40 & - \\
Kolca Obruğu & 1995 & 1033 & 52 & 26 & - \\
Yavşan Obruğu & 2000 & 1040 & 21 & 69 & + \\
Küpbasan Obruğu & 2006 Nisan & 1002 & 19 & 6 & - \\
Seyithacı Obruğu I & 2007 Nisan & 1009 & 15,25 & 1,06 & - \\
Seyithacı Obruğu II & 2007 Haziran & 1009 & 17,5 & 4,5 & - \\
Seyithac1 Obruğu III & 2007 Temmuz & 1009 & 24,95 & 7,8 & - \\
Akkuyu Obruğu I & 2007 Ağustos & 1022 & 15,7 & 2,1 & - \\
Seyithac1 Obruğu IV & 2007 Kasım & 1008 & 3,2 & 4,5 & - \\
Akviran Obruğu I & 2007 Aralık & 1045 & 2 & 0,5 & - \\
Akkuyu Obruğu II & 2008 Ağustos & 1008 & 15 & 1 & - \\
Seyithacı Obruğu V & 2008 Ekim & 1008 & 11,6 & 2,5 & - \\
Seyithacı Obruğu VI & 2008 Ekim & 1011 & 4,5 & 6,6 & - \\
Inoba Obruğu & 2008 Kasım & 1010 & 24 & 35 & + \\
Akkuyu Obruğu II (Yarımoğlu) & 2009 Şubat & 1008 & 24,8 & 35,8 & + \\
Eşeli Obruğu & 2009 Şubat & 1036 & 15,9 & 0,85 & - \\
\hline & & \multicolumn{5}{c}{ Kaynak: Doğan ve Y1lmaz, 2010 }
\end{tabular}

Son 4 yıl içerisinde Karapınar çevresinde oluşan 13 obruktan yalnızca iki tanesi İnoba ve Akkuyu III (Yarımoğlu obruğu) boyutları ve oluşturdukları tehlike nedeniyle ulusal medyaya yansımıştır. Diğerleri hem oluşum yeri itibariyle daha kuzeyde yaylada yer almaları hem de çok büyük oluşum olmamaları nedeniyle fazla dikkat çekmemiştir.

Obruk Platosu ile doğudaki Karapınar Ovası arasında dar bir eşik üzerinde kurulmuş olan Seyithacı Yayla yerleşmesi içerisinde ve çevresinde, Nisan 2007-Ekim 2008 tarihleri arasında, farklı boyutlarda 6 tane obruk oluşmuştur. Seyithacı obruklarından 4'ü yerleşim alanına bir kaç yüz metre uzakta yer alan tarım alanları içerisinde, genişlikleri diğerlerinden daha büyük olan 2 tanesi (Seyithacı II ve III obruğu) ise yerleşim alanının içerisinde oluşmuştur. Seyithacı II Obruğu yerleşim alanına ulaşan karayolunun yalnızca $10 \mathrm{~m}$ batısında ve bir patika yolun tam ortasında oluşmuştur (Foto 1). Yayladaki evlere ise yalnızca $30 \mathrm{~m}$ uzaktadır. Yerleşim alanı içerisindeki Seyithacı III Obruğu, yerleşim alanının kuzey kesiminde, yola ve evlere $30 \mathrm{~m}$ uzaktadır.

Küpbasan Obruğu, 2006 yılı Nisan ayında Küpbasan Yayla yerleşmesinin tam ortasında oluşmuştur. Obruk daha sonra yaylada yaşayan halk tarafından molozla doldurulmaya çalışılmıştır. Obruk oluşumuyla birlikte çevresindeki evlerin duvarlarında küçük çatlaklar meydana gelmiştir. Yayla yerleşmesi içinde oluşmuş olan bu obruk yöre halkı için oldukça büyük bir tedirginlik yaratmaktadır. Arazi çalışmaları esnasında obruk çevresi Karapınar belediyesi tarafından tel çit ile kapatılmıştır.

İnoba obruğu 2008 yılının son aylarında Karapınar'ın yaklaşık 30 km. güneybatısındaki İnoba yaylası batısında oluşmuştur. Obruk, yerleşim alanındaki evlerin yalnızca $50 \mathrm{~m}$ uzağında İnoba yerleşmesini doğudan çevreleyen ve ovadan $10 \mathrm{~m}$ yüksek olan alçak plato üzerinde yer alır. $24 \mathrm{~m}$ çapında ve $35 \mathrm{~m}$ derinliğinde olan obruk yeraltı suyunu kestiği için içerisinde göl bulunmaktadır (Foto 3). Obruk oluşumundan önceki birkaç gün içerisinde yaylada yaşayan halk yeraltından gelen patlamayı andıran sesleri duyduklarını belirtmişlerdir. Obruk İnoba Yayla'sında yaşayan ve genellikle küçükbaş hayvancılık yaparak geçimini sağlayan yöre halkı için büyük bir tehlike oluşturmaktadır. Bölgede hayvanları ile birlikte bulunan çobanlar koyun sürülerini obruğun oluştuğu merada 
otlatmaktadır. Obruğun meydana geldiği alanda otlayan hayvanlar ve dikkatsiz olan çoban yada yöre halkı özellikle akşamları obruğa düşme tehlikesi ile karşı karşıyadır.

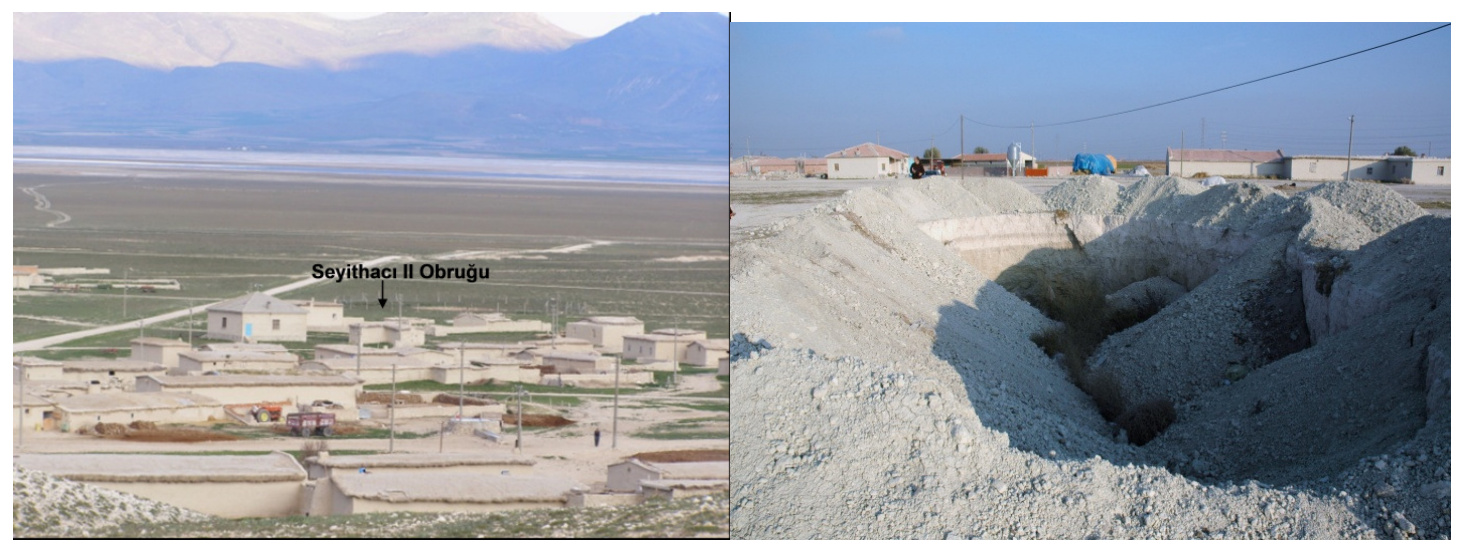

Foto 1. Seyithac1 II Obruğu ve Yaylası .

Foto 2. Küpbasan Obruğu.

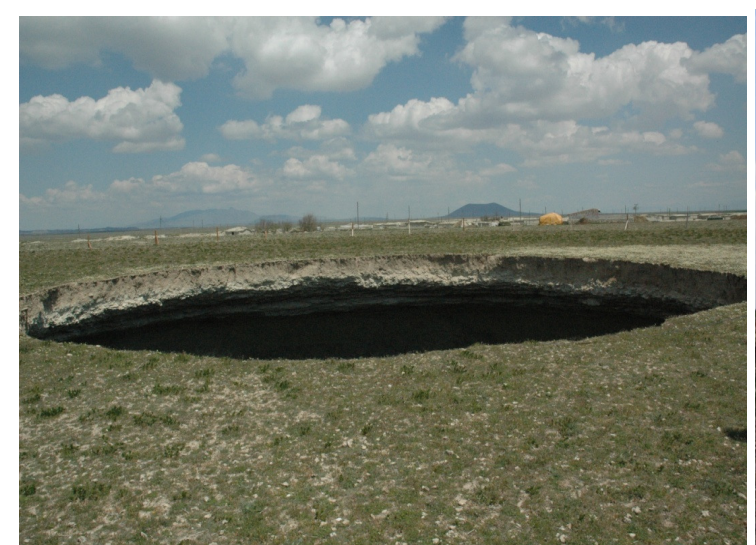

Foto 3. İnoba Obruğu.

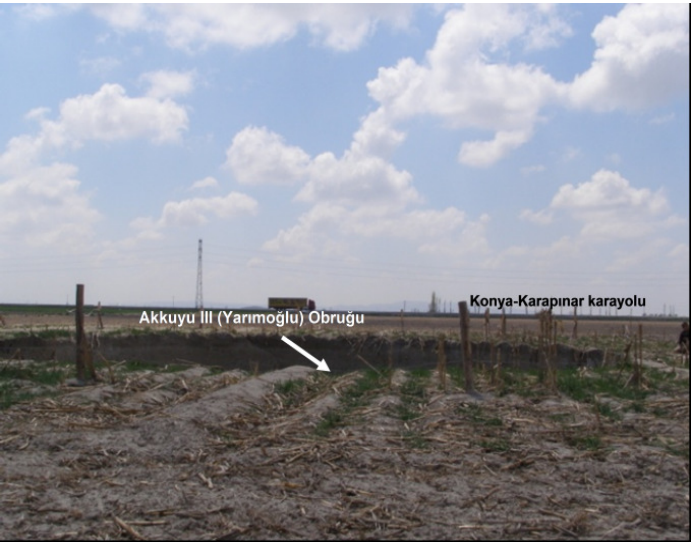

Foto 4. Akkuyu III(Yarımoğlu) obruğu.

Akkuyu Yaylası yakınlarında 2007-2008 yıllarında 3 obruk oluşmuştur. Bu üç obruktan ilk ikisi oluşum sırasına göre; Akkuyu I, Akkuyu II olarak isimlendirilmiştir. Boyut olarak en büyük olan Akkuyu III obruğuna yerel halk tarafından Yarımoğlu Obruğu adı verilmiştir. Akkuyu I ve Akkuyu II obrukları çok büyük olmadıkları için çok fazla dikkat çekmemiştir. Akkuyu III (Yarımoğlu) Obruğu, Karapınar'ın 15 km batısında Konya-Karapınar karayolunun yalnızca 200 m kuzeyinde ve Akkuyu Yayla'sındaki çiftlik evlerinin yaklaşık 500 m uzağındadır. 2009 yılı şubat ayında $1008 \mathrm{~m}$ yükseltide oluşan obruk kuzeydeki plato ile güneydeki ova arasındaki az eğimli yamaçtaki bir tarlanın içerisindedir. Derinliği $35.8 \mathrm{~m}$ olan obruğun ağız genişliği K-G doğrultusunda $20.4 \mathrm{~m}$, D-B doğrultusunda 24.8 m'dir (Foto 4). Obruğu kuşatan birkaç metrelik alan içerisinde görülen çok sayıdaki çatlak ve obruğun yamaç profili gelecekte olacak genişlemenin işaretidir. Su tablasını kesen obruğun tabanında göl bulunmaktadır. Akkuyu III (Yarımoğlu) Obruğu Konya-Karapınar karayolunun çok yakınında olması ve yoğun olarak ekonomik faaliyet yapılan bir alanda bulunması nedeniyle ulusal basına yansımıştır. Tarlada mısır hasadı yapılırken ani bir çökme sonucu meydana gelen Akkuyu III (Yarımoğlu) Obruğu'nun özellikle Konya-Karapınar karayoluna çok yakın bir yerde (yaklaşık 200 m kuzeyinde) oluşması bölgede yaşayan insanları tedirgin etmiştir. Oluştuğu dönemde özellikle bölgede yaşayan halk ve araştırmacılar tarafından incelenmek için gezilen obruk basit bir dikenli tel ile çevrilmiştir. Obruk çevresinde bulunan tansiyon çatlakları obruğun gelişiminin hala 
devam etmekte olduğunu ve çapının genişleyeceğini bize göstermektedir. Ciddi bir koruma tedbirinin bulunmadığı obruk ziyaret edenler açısından büyük bir büyük bir risk taşımaktadır.

\subsubsection{Göl ve bataklıkların kuruması}

Araştırma alanı KKH'nın bir parçasıdır. Havzayı bir bütün olarak değerlendirdiğinizde içinde 11 adet sulak alan bulunmaktadır. Bunlardan Karapınar Sazlığı ve Hotamış Sazlığı'nın doğu kısmı inceleme alanı içinde yer almaktadır. Ayrıca Acıgöl ve Türkiye'deki 12 Ramsar alanından biri olan Meke Maarı inceleme alanı içindedir. Bunların dışında Meyil, Çıralı gibi içinde su bulunan obruklar da bölgedeki sulak alanları oluşturmaktadır. Bunların dışında inceleme alanında bir sürü kaynak ve yaz aylarında kuruyan dereler bulunur.

Kuraklık ve yeraltı suyu seviyesin gerilemesine bağlı olarak bölgedeki göl ve bataklık alanları ciddi tehdit altındadır. Durduran (2008) yapmış olduğu çalışmada (1990-2000 yılları arası) Karapınar Sazlığı'nın \%43.43, Hotamış Sazlığı'nın \%27.85 oranında kuruduğunu tespit etmiştir. Bunlardan Karapınar Ovası bahar aylarında su yüzeyi yarım metreyi geçmeyen aşırı tuzlu bataklık görünümündedir. Bataklık $19 \mathrm{~km}^{2}$ bir alan kaplar Ancak, son y1llarda yetersiz beslenme ve yeraltı su seviyesindeki gerilemeye bağlı olarak bu sulak alanda $15.2 \mathrm{~km}^{2}$ lik bir bölüm tamamen özeliğini yitirmiş durumdadır (Tunçez ve Candan 2008). İnceleme alanı batısında yer alan Hotamış Bataklıkları içinde benzer bir durum geçerlidir. Hotamış Sazlığı'nda da $16.5 \mathrm{~km}^{2}$ lik bir alan sulak alan özelliklerini kaybetmiştir.

Meke Maarı inceleme alanındaki sulak alanlardan bir diğeridir (Foto 5). Volkanik bir patlama sonunda oluşan çukur içinde daha sonra piroklastik bir koni meydana gelmiştir. İki volkanik ünite arasında kalan çukur alanlara suların birikmesiyle bir göl meydana gelmiştir (Sür, 1972; Somuncu, 1986). Bu güzel görünümü ile Meke Maarı, dünyada eşine az rastlanan tabiat güzelliklerinden biridir. Meke Maarı ve çevresi 1. Derecede doğal sit alanıdır. Ayrıca 260 hektarlık kısmı Tabiat Anıtı stasüsünde olup, 2005 yılında 202 hektarlık bir bölümü Ramsar alanı olarak ilan edilmiştir (Tunçez ve Candan, 2008; Tapan vd., 2008). Ancak bu alan doğal ve beşeri çeşitli sorunlarla karşı karşıyadır. Çok derin (en derin yeri $1.5 \mathrm{~m}$ ) olmayan göl alanı yaşanan kuraklığa bağlı olarak küçülmüştür (Foto 6). Ayrıca maar çevresinden yasak olmasına rağmen geçmiş yıllarda briket yapımı için piroklastik malzemeler alınmıştır (Somuncu, 1986). Bu da çevrenin doğal görünümünün bozulmasına neden olmuştur.

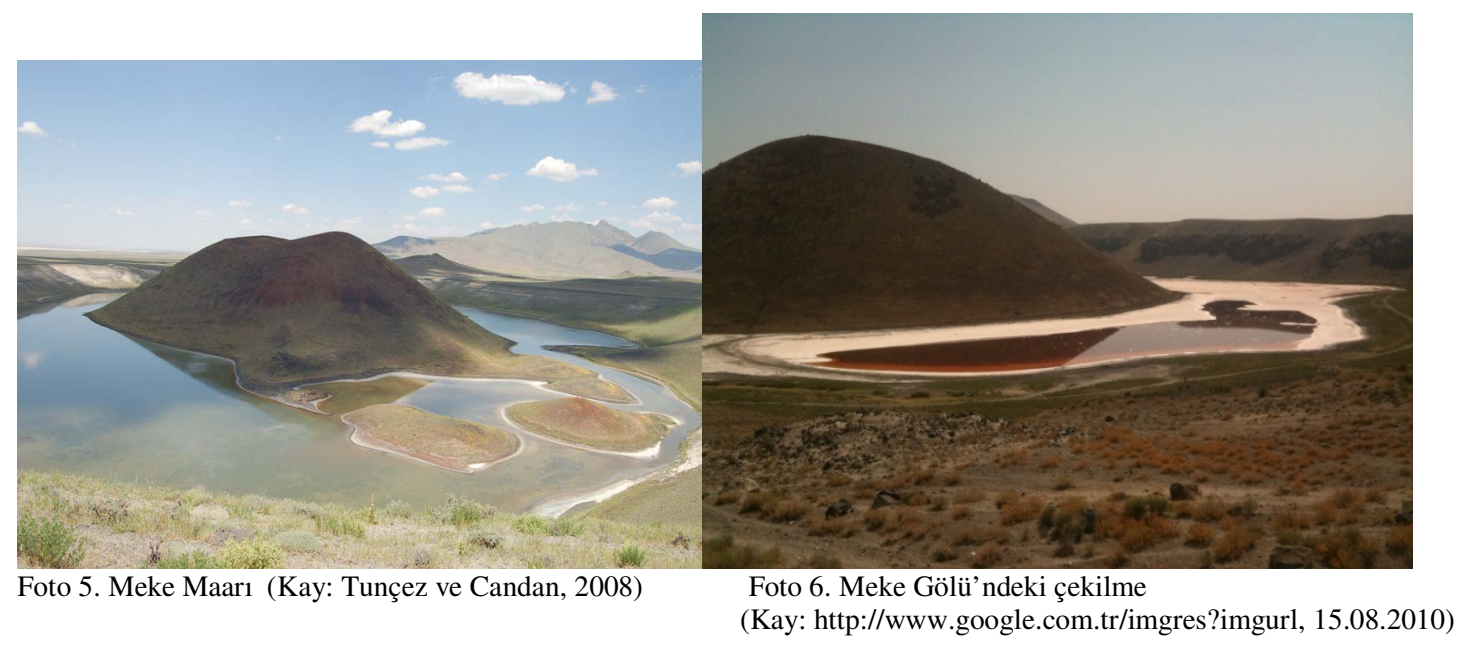

Bölgenin ekolojik özeliklerine baktığımızda göl ve çevresi step bitki örtüsü ile kaplıdır. Göl kıyısında sazlar ve tuzcul su bitkileri yetişmektedir. Ayrıca göl suları tuzlu ve sodalı olduğundan 
bölgede çok fazla kuş türü bulunmasa da bozkaz, suna, kızıl şahin, puhu gibi kuş türleri yaşamaktadır (Tapan vd., 2008).

Araştırma alanında yer alan volkanizmaya bağlı olarak oluşmuş olan diğer bir yer şekli ise Acıgöl'dür. Karapınar-Ereğli karayolu kuzeyinde yer alan göl 1,5 km çapındadır. Suları oldukça sülfatlı ve tuzlu olan gölde de seviye düşmeleri açık bir şekilde gözlemlenmektedir (Bozyiğit ve Tapur, 2009).

Göl seviyelerindeki bu düşüş içerisinde su bulunan obruklarda da görülmektedir. Çıralı ve Meyil araştırma alanında içinde su bulunan obruklardır. Bayarı vd., (2009) Obruk paltosunda yer alan Çıralı Obruğu'ndaki göl seviyesinin 1970 yılların sonlarına göre 2003 yılı ağustos ayında $30 \mathrm{~m}$ düştüğünü hesaplamıştır. Aynı durumu Meyil obruğunda gözlemleme mümkündür. Bu obruğa ait bir ölçüm bulunmamakla birlikte arazi çalışmalarında göl seviyesindeki düşme açık bir şekilde gözlemlenmiştir.

\subsubsection{Topraktaki çoraklaşma ve tuzlanma}

Sulama tarımsal alanlarda verimi çok önemli boyutlarda artırmaktadır. Ancak suyun bitkiye olan faydası yanında sulamanın yapıldığı toprağa zararları da olabilmektedir. Bazı hallerde kontrolsüz yapılan sulama faaliyetleri sonucunda geniş tarım arazileri çorak, tuzlu topraklar haline gelebilmektedir. Bu tür alanların örneklerini Türkiye'de sık görmek mümkündür.

KKH'da yetersiz drenaj ve bilinçsiz sulama nedeniyle oluşmuş 325.000 hektar çorak arazi bulunmaktadır (Zengin vd., 2008). Bu Konya Ovası'nın yaklaşık \%6'lık bir kısmını oluşturur. Araştırma alanı olan Karapınar çevresinde bu havza içinde yer aldığından ve yoğun sulama faaliyetleri içinde bulunduğundan dolayı bu çoraklaşmanın en fazla hissedildiği alanlardan biridir. Bu sorun sulu tarım deneyimi hiç olmayan veya çok az olan çiftçilerin yaptığı hatalı ya da aşırı sulamalar, bölgenin topografik yapısı, toprak özelikleri, iklim koşulları, yetersiz drenaj gibi sebeplerden dolayı ortaya çıkmaktadır.

Tuzlanmanın tarımsal faaliyetler üzerindeki olumsuz etkilerinden biriside tuzlanan toprakların gelecekte gerekli sslah çalışmaları yapılmadığı takdirde kullanılamaz hale gelmesidir. Toprakta tuzların birikimiyle birlikte belirli bir süre sonra verim alınamamaktadır. Topraktaki verimin azalmasıyla da artık bitki yetişemeyecek duruma gelmektedir. Böyle bir durumda ekim yapılan toprak terk edilmekte ve tarım dişı kullanıma kalmaktadır.

Karapınar çevresinde sulu tarım alanları 2000 yılından sonra hızlı bir şekilde artmıştır. Ancak çiftçilerin sulu tarım kültürünü çok iyi bilmemeleri, toprakların yeterince drene edilememesi, bitkinin ihtiyacından fazla su kullanılması gibi nedenlerden dolayı bu bölgede de topraklarda çoraklaşma ve tuzlanma sorunu ortaya çıkmıştır. Kuru tarım alanlarının sulamaya açılması sonucu suların içerdiği iyonların uygun bir drenaj sistemiyle bünyeden uzaklaştırılamayan bölümü özellikle kurak ve yarı kurak bölgelerde toprakta birikmeye başlamaktadırlar. Bu da toprakta tuzluluk ve alkalilik sorunun ortaya çıkarmaktadır (Bahçeci vd., 2008) . Sulama yapılan tarım alanlarında ortaya çıkan tuzlulaşma çukur bir topografyaya sahip, uzun süre yağış alamayan ve yüksek buharlaşmanın olduğu Karapınar ve Hotamış ovalarında önemli ölçüde görülmektedir. Bu alanlarda toprakta oluşan çoraklaşma sonucu topraktaki verim kısa süre sonra azalır. Bölgede kurak ve sıcak geçen yaz aylarında toprak yüzeyinde tuz birikmeleri görülür ve sadece tuzluluğa karşı dayanıklı olan bitkilerin verimliliği bir süre daha devam edebilir. Toprakta çoraklaşma ve alkalileşme toprağın hem fiziksel hem de kimyasal özelliklerini iyice bozar ve sadece tuzcul topraklan seven halofitler yetişme olanağı bulabilir.

Topraktaki tuzlanma sorunu çözebilmek için öncelikle gelişmiş bir drenaj sisteminin kurulmasıdır. Sulama ve drenaj sistemleri birbirinden ayrılmayan ve birlikte işlemesi gereken bir faaliyettir. Ancak Türkiye'de sulama yapılan hemen hemen her bölgede yeterli drenaj sistemlerinin kurulmadığından dolayı çok ciddi çevre sorunlarıyla karşılaşılmaktadır. Bundan dolayı sulamaya geçilen alanlarda drenaj ve sulama sistemleri birlikte kurulmalıdır. 


\section{Sonuç}

Karapınar çevresinde su tablasındaki alçalma ve mevsimsel oynamalar yeni obruk oluşumuna neden olmaktadır. Son yıllarda oluşan obrukların bulundukları yükseltiler ve dağılışları, çökmeleri tetikleyen su tablası alçalmasını doğrular niteliktedir. Son 33 yıl içerisinde oluşan obruklardan 2001 yılı öncesine ait olanların tamamı platoda yer alırken, bu yıldan sonra oluşanların biri dışında diğerleri plato ve ova arasındaki yamaçlarda ve ovadan $10 \mathrm{~m}$ yüksekte olan eşik üzerinde oluşmuşlardır. Son yıllarda yeraltı su seviyesinin daha fazla düşmesi ovaya yakın kesimlerdeki obruk oluşumu için uygun koşulları hazırlamıştır.

Önümüzdeki yıllarda da su tablasındaki alçalma devam edecek olursa, oluşması muhtemel olan obrukların büyük oranda son yıllarda oluşanlar ile aynı alanlarda veya Karapınar ve Hotamış ovalarının Obruk Platosu'na komşu olan bölümleri (Seyithacı, Küpbasan, Akkuyu yaylaları başta olmak üzere) ve daha göneyde yer alan İnoba Yaylası ve çevresi için risk oluşturacağı söylenebilir. Aynı risk az bir oranda da Obruk Platosu'ndaki yerleşmeler (Akviran, Kolca, Sekizli, Eşeli Yayla vb.) için geçerlidir. Risk altında olan bu alanlar, su tablasının bugünkü seviyelerde veya biraz daha aşağıda olduğu geçmişteki kurak iklim dönemlerinde obruk oluşumunun meydana geldiği alanlardır.

2001 yılından önce oluşan obruklar Obruk Platosu'nda genellikle ulaşımın ve ekonomik faaliyetlerin yoğun olmadığı alanlarda meydana gelmiştir. Bu obrukların daha çok hayvancılıkla uğraşan ve birkaç ailenin yaşadığı mevsimlik yayla yerleşmelerinin yakınlarında oluşmaları can ve mal güvenliği açısından riski azaltmıştı. Bununla birlikte 2006-2009 yılları arasında oluşan obrukların yerleşim alanları içerisinde ya da çok yakınında (Seyithacı, Küpbasan ve İnoba obrukları) ve karayolunun kenarında (Akkuyu III Obruğu) meydan gelmesi can ve mal güvenliğini daha çok tehdit eder duruma gelmiştir.

Genç obrukların oluştuğu alanlarda hatta ova kenarlarında ve kısmen platoda bundan sonra oluşması muhtemel obrukların can ve mal kaybına yol açmamaları için hemen yeraltından su çekimi hızla azaltılmalı. Bölgede yeraltından su çekimi ruhsatlı kuyularda kontrol altına alınarak yapılmalıdır. Böyleye yeraltı suyu alçalmalarındaki insan etkisi dahada azaltılabilir. Başta Seyithacı, Küpbasan, İnoba, Akkuyu yerleşmeleri ve Karapınar-Konya yolu çevresinde ve platoda bazı yerleşim alanlarındaki yeraltı boşluklarının tespit edilmesi için acilen harekete geçilmelidir. Hatta Seyithacı ve İnoba, Küpbasan başta olmak üzere çökme riski olan yerleşmeler altındaki boşluklar jeofizik yöntemleri ve sondajlarla belirlenene kadar insanlar güvenli alanlara taşınmalıdır.

Araştırma alanı olan Karapınar'ın da içinde yer aldığı KKH'sında küresel iklim değişmeleri ve mevsim değişiklerine bağlı olarak son 25-30 yıldır yağışlarda ciddi bir azalma görülmektedir. Bu azalmada Kuzay Atlantik Salınımı'nın da etkisi vardır. Uzun süreli verilere dayalı olarak belirlenen kuraklık yeraltı sularının yeterli beslenememesi sorununu ortaya çıkarmaktadır. $\mathrm{Bu}$ çeşitli sosyoekonomik sorunları da beraberinde getirmektedir. Genel olarak bölgede yağışların özellikle kış ve ilkbahar mevsimlerinde düşmektedir. Bu dönemlerdeki yağış azalmalarının yeraltı su kaynaklarının beslenmesi, tarımsal üretim ve bölgede yaşayan halkın yaşam kalitesi açısından çok önemli olduğunu belirtmek gerekir. Kurak sonucu ortaya çıkan tarımsal üretim azalmaları, temiz su kaynaklarına erişimin zorlaşması gibi nedenlerle ilerleyen yıllarda bölgeden yaşanacak olan göçün daha da şiddetlenerek tarımsal toprakların terk edilmesi sonucunu doğurabilir.

Tarım ve hayvancılık araştırma alanındaki en önemli ekonomik faaliyet koludur. Bölgede geleneksel olarak kuru tarım (özellikle tahıl tarımı) ve mera hayvancılığı yaygındır. Ancak bölgede özellikle 2000 yılı sonrasında Karapınar ve Hotamış ovalarında yeraltı suyuna bağlı olarak sulu tarım alanları artmaya başlamıştır. 2000-2009 yılları arasında Karapınar'da şekerpancarı ekim alanları 55.910 dekardan 103.809 dekara, mısır ekim alanları 1.210 dekardan 69.648 dekara çıkmıştır. İlçede 2000 yılında hiç mısır ekimi yapılmazken bu değer 2009 yılında 20.585 dekara ulaşmıştır. Bölgenin doğal vejetasyon şartlarına aykırı olan bu ürünler yoğun bir şekilde sulama ile yetiştirilebilmektedir. Örneğin şekerpancarını yetişebilmesi için $825 \mathrm{~mm}$, mısır için $685 \mathrm{~mm}$, ayçiçeği için $615 \mathrm{~mm}$ ve yonca için $1200 \mathrm{~mm}$ suya ihtiyaç vardır. Karapınar'da ortalama yıllık yağışın $283.9 \mathrm{~mm}$ olduğu gerçeğini düşünürsek durum tüm net bir şekilde ortaya koymuş oluruz. Su isteği yüksek olan bu tür bitkilerin 
ekim alanlarındaki genişlemeye bağlı olarak yeraltı su seviyesinde bu yıllarda çok hızlı bir şekilde düşmüş̧ür.

KKH toplam emniyetli yeraltı suyu rezervi yıllık yaklaşık 1.8 milyar $\mathrm{m}^{3}$ iken çekilen yıllık su miktarı 2.6 milyar $\mathrm{m}^{3}$ tür. Bu verilere göstermektedir ki araştırma alanındaki en önemli tehditlerden biri bölgedeki tarımsal sulamanın sürdürülebilir olmamasıdır. Aşırı sulama nedeniyle yeraltı akiferlerinde her geçen yıl daha da gerileyen su yok olma tehlikesiyle karşı karşıyadır. Bu durumda sadece tarımsal sulama değil, yeraltı sularını içme suyu olarak kullanan insan ve hayvanların da su temini güçleşecektir.

Bölgede yapılan çalışmalarda yeraltı suyu seviyesindeki gerilemeler açıķa ortaya çıkmaktadır. Araştırma alanında daha önce yapılan çalıșmalar ve DSİ'nin yeraltı suyu seviye verilerine göre su seviyesi yaklaşık son 40 yılda su seviyesi $22-25 \mathrm{~m}$ civarında alçalmıştır. Bölgedeki kuyulardan elde edilen verilere göre bu gerilemenin önemli bir k1smı 2000 y1lından sonra gerçekleşmiştir. Havzadaki yeraltı suyu seviyesinin düşmesine ve bazı akiferlerin özelliğini kaybetmesine bağlı olarak da pek çok bataklık ve kaynak kurumuştur. Ayrıca araştırma alanında yer alan göllerin de seviyeleri alçalmıştır.

Araştırma alanı içinde Karapınar ve Hotamış sazlığı gibi sulak alanlar bulunmaktadır. Ayrıca Meke Maarı, Acıgöl gibi volkanizma sonucu oluşmuş morfolojik ünitelerde ve Çıralı, Meyil gibi karstik obruk gölleri bu sulak alanlar içindedir. Bölgedeki sulak alanlar hissedilen kuraklık, yeraltı suyu seviyesindeki gerileme ve çeşitli beşeri etkiler yüzünden önemli ölçüde tehdit altındadır. Yapılan çalışmalarda Karapınar ve Hotamış sazlıklarının büyük bölümünün sulak alan özelliğini yitirdikleri ortaya çıkmıştır. Meke, Acıgöl, Çıralı ve Meyil göllerinde de su seviyeleri geçmiş yıllara göre büyük ölçüde düşmüştür. Bunu önlenebilmesi için sulak alanları besleyen akarsu ve kaynakların korunması ve özellikle Hotamış ve Karapınar ovalarında binlerce olan su kuyularının kontrolsüz bir biçimde yeraltından su çekmesinin önüne geçilmelidir.

Karapınar çevresinin kurak bir iklime sahip olması toprakların tuzlanmasına uygun bir koşul hazırlamaktadır. Bölgede yetersiz yağış nedeniyle topraktan yıkanıp uzaklaşmayan tuzlar, aşırı ve bilinçsiz sulama nedeniyle önemli bir çevre sorunu yaratmaktadır. Bazı hallerde kontrolsüz yapılan sulama faaliyetleri sonucunda geniş tarım arazileri çorak, tuzlu topraklar haline gelebilmektedir. Araştırma alanında sulu tarıma geçilmesiyle birlikte yetersiz drenaj ve aşırı sulama nedeniyle oluşan çorak arazilerin alanı artmaktadır. Topraktaki tuzlanma sorunu çözebilmek için öncelikle gelişmiş bir drenaj sisteminin kurulması gerekmektedir.

Bölgede su tüketimini artıran salma sulama yöntemine izin verilmemeli ve tüm sulama kontrollü ve basınçlı sulama sistemleri ile yapılmalıdır.

Tuzlanma tarım topraklarını tehdit eden önemli çevre sorunlarından biridir. Tarım topraklarının tuzlanması hem toprakların üretim dışı kalmasına hem de önemli bir doğal kaynak olan topraklarımızın elden çıkmasına neden olmaktadır. Bu durum sürdürülebilir tarım imkânlarını tehdit ettiği gibi KKH topraklarının geleceği açısından da kaygı vermektedir. Bunun için havza genelinde çok iyi drenaj sistemi yapılarak sorunun önüne geçilmelidir.

\section{Teşekkür}

$\mathrm{Bu}$ çalışma konusunun belirlenmesi ve arazi çalışmaları sırasından birlikte olduğumuz bölümümüz öğretim üyelerinden Doç.Dr. Uğur Doğan'a çok teşekkür ederim. Ayrıca arazi çalışmaları sırasında bizlere yardımcı olan ve bilgi veren Karapınar'dan Musa Ceyhan ve İnoba Yaylası'ndan Mehmet Köroğlu'na katkıları dolayısıyla teşekkür ederim. DSİ'den gerekli verilerin temininde yardımlarını esirgemeyen Özlem Kırdım ve Mert Toklu'ya da buradan teşekkür ederim. 


\section{Kaynaklar}

Anonim, 2010. Konya Kapalı Havzası, (http://www.wwf.org.tr/page.php?ID=12, 14.07.2010)

Bahçeci, İ., Tarı, A.F. ve Dinç N. 2008. Konya Ovasında Kontrollü Drenaj Sulama Etkinliği ve Toprak Tuzlanması Üzerine Etkisinin Saltmod ile Tahmin Edilmesi. Harran Üniv. Zir. Fak. Dergisi, 12 (2), 69-77.

Bayarı, C.S., Pekkan, E. and Özyurt, N, N. 2009. Obruks, as Giant Collapse Dolines Caused by Hypogenic Karstification in Central Anatolia, Turkey: Analysis of Likely Formation Processes. Hydrogeology Journal,17, 327-345.

Biricik, A.S. 1992. Obruk Platosu ve Çevresinin Jeomorfolojisi. Marmara Üniversitesi Yay. No: 531, İstanbul.

Bozyiğit,R. ve Tapur,T. 2009. Konya Ovası ve Çevresinde Yeraltı Sularının Obruk Oluşumlarına Etkisi. Selçuk Üniv.Sos. Bil. Enst. Dergisi, 21, 137-155.

Bulduk, A., Horasan Ö.R., Tekdere, M. ve Solak N. 2008. Konya Kapalı Havzasın 16/2-a Alt Havzasında Yeraltı Suyu ve Seviye Değişmeleri. Konya Kapalı Havzası Yeraltı Suyu ve Kuraklık Konferansı, Bildiri Kitabı:125-134,11-12 Eylül 2008, Konya.

Buldur, A.D. 2001. Karapınar'ın (Konya) Coğrafi Özelikleri, Karapınar Sempozyumu, Bildiri Kitabı: 317-337, 26-27 Ekim 2000, Karapınar.

Canik, B. ve Arıgün, Z. 2001. Karapınar-Kızören (Konya) Dolayındaki Obrukların Oluşumu ve Karapınar Volkanizmasının Bu Olaya Etkisi, Karapınar Sempozyumu Bildiri Kitabı: 295-303, 26-27 Ekim 2000, Karapınar.

Canik, B. and Çörekçioğlu, İ. 1985. The Formation of Sinkholes (Obruk) Between Karapınar and Kızören-Konya, Karst Water Resources (Proceedings of Ankara-Antalya Symposium, July 1985) IAHS Publ.no.161,193-205.

Çörekçioğlu, İ. 1985. Konya-Karapınar-Kızören Arasındaki Obrukların Oluşumu ile İlgili Hidrojeoloji Etüt Raporu. DSİ IV. Bölge Müdürlügüü, Konya.

DMİ. 2010. Yıllık Yağış ve Sicaklık Verileri, (http://www.meteor.gov.tr/veridegerlendirme/il-veilceler-istatistik.aspx, 08.07.2010)

Doğan, U.,Çiçek, İ. 2002. Occurence of Cover-Collapse Sinkholes (Cover-Collapse Dolines) in the May Dam Reservoir Area (Konya, Turkey). Cave and Karst Science, 29 (3), 111-116.

Doğan, U. 2004. Dolin Sınıflamasında Yeni Yaklaşımlar, Gazi Üniv. Gazi Eğitim Fakültesi Dergisi, 24 (1), 249-269.

Doğan, U., Yılmaz, M. (2010) "Natural and induced sinkholes of the Obruk Plateu and the KarapınarHotamış Plain, Turkey", Journal of Asian Earth Sciences, doi:10.1016/j.jseaes.2010.09.014

Doğdu, M.Ş., Toklu, M.M. ve Sağnak. C. 2007. Konya Kapalı Havzası'nda Yağış ve Yeraltı Suyu Değerlerinin İrdelenmesi, I. Türkiye İklim Değişikliği Kongresi, Bildiri Kitabı:394-402, 11-12 Nisan 2007, İstanbul.

D.S.İ,. 2010. 52258, 52268,43664, 38306 Nolu Kuyuların YAŞ Seviye Verileri. Ankara.

Durduran,S.S. 2008. Konya Kapalı Havzasındaki(KKH) Sulak Alanlara Ait Alansal Değişimin Coğrafi Bilgi Sistemi ve Uydu Görüntüleriyle Tespit Edilmesi, Yeni İpek Yolu Dergisi, (http://www.kto.org.tr/tr/dergi/dergiyazioku.asp?yno=1498\&ano=89, 15.08.2010.

Erinç, S.1960. Konya Bölümünde ve İç Toros Sıralarında Karst Şekilleri. Türk Coğrafya Dergisi, 20, 83-106.

Erinç, S., 2001. Jeomorfoloji II (Güncelleştirilmiş 3. Basım). Der Yayınları, İstanbul.

Erol, O., 1971. Konya, Tuz Gölü, Burdur Havzalarındaki Pluvial Göllerin Çekilme Safhalarının Jeomorfolojik Delilleri. Coğrafya Araştırmaları Dergisi, 3-4, 13-52.

Erol, O.1990. Konya-Karapınar Kuzeybatısındaki Obrukların Jeomorfolojik Gelişimi ile Konya ve Tuzgölü Pleyistosen Pluviyal Göller Arasındaki İlişkiler, İstanbul Üniv. Deniz Bilimleri ve Coğrafya Enstitüsü, Bülten, 7, 5-50.

Eroskay, O. 1976. The Factors Influencing the Konya Obruks and Their Groundwater Potentials Evaluation. İstanbul Üniv. Fen.Fak. Mec., Seri. B.41,5-14. 
Göçmez, G., Dıvrak, B.B. ve Galena, İ. 2008a. Konya Kapalı Havzası'nda Yeraltı Suyu Seviyesinin Değişiminin Tespiti Özet Raporu. WWF, İstanbul.

Göçmez, G., Genç, A. ve Karakoca, A. 2008b. Konya Kapalı Havzası Yeraltısuyu Seviye Değişiminin İstatistiksel Değerlendirilmesi. Konya Kapalı Havzası Yeraltı Suyu ve Kuraklık Konferansı, Bidiri Kitabı:98-107, 11-12 Eylül 2008, Konya.

Gümüşçü, O. ve Yılmaz, M. 2001. Ulaşım Şartlarının Ortaya Çıkardığı Şehir: Karapınar'ın Kuruluş Öyküsü. Karapınar Sempozyumu, Bildiri Kitabı: 53-68, 26-27 Ekim 2000, Konya-Karapınar.

Gürler, G. And Timur, E. 2007. Determination Of Conservation \& Usage Methods Of Geoparks-A Critical Assessment For Karapinar Potential Geopark Site,Turkey, Second International Symposium on Development Within Geoparks-Environmental Protection and Education, 1215 June, 2007, Lushan-Jiangxi Province-China.

İşçioğlu, A. 2008. Konya Kapalı Havzasındaki Su Tahsisi ve Kullanımına Genel Bir Bakış. Konya Kapalı Havzası Yeraltısuyu ve Kuraklık Konferansı, Bildiri Kitabı:135-142, 11-12 Eylül 2008, Konya.

Kara, M., Toprak, R., Şahin, M., Süheri, S. ve Yavuz, D. 2008. Konya Ovasında Sulamada Yeraltı Suyu Tüketiminin Azaltılması Çareleri. Konya Kapalı Havzası Yeraltısuyu ve Kuraklık Konferansı, Bildiri Kitabı:51-56, 11-12 Eylül 2008, Konya.

Karadoğan, S., 2001. Karapınar Çevresindeki Farklı Jeomorfolojik Şekiller, Özelikleri ve Turizm Potansiyelleri. Karapinar Sempozyumu, Bildiri Kitabı: 339-358, 26-27 Ekim 2000, KonyaKarapinar.

KHGM., (2010) Yeşeren Çöl:Karapınar. (http://www.khgmgov.tr,10.10.2010)

Lowe, D. ve Waltham, T. 2002. Dictionary of Karst and Caves. Lancaster: BCRA Cave Studies Series 10.

Polat, A.T., (2008) Ekoturizm Karapınar İlçesi ve Yakın Çevresi. Karapınar Belediyesi Yayını, Konya.

Roberts, N., Erol O., Meester, T. and Uerpmannn, H.P. 1979. Radiocarbon Chronolagy of Late Pleistocene Konya Lake, Turkey. Nature, 281.5733, 662-664.

Roberts, N., Black,S., Boyer, P., Eastwood, W.J., Griffiths, H.I., Lamb, H.F., Leng, M.J., Parish, R., Reed, J.M., Twigg, D. and Yiğitbaşıŏlu, H. 1999. Cronology and Stratigraphy of Late Quaternary Sediments in the Konya Basin, Turkey: Results from the KOPAL Project. Quaternary Science Reviews, 18, 611-630.

Somuncu., M. 1986. Bozkırdaki Doğal Anıtlar: Acıgöl Maarı ve Meke Tuzlası, TÜBITTAK Bilim ve Teknik Dergisi, 19 (225), 42-44.

Sür., Ö. 1972. Türkiye’nin Özelikle İç Anadolunun Genç Volkanik Alanlarının Jeomorfolojisi. Ankara Üniv. DTCF Yay. No. 223, Ankara.

Tapan, D.S., Ayas, C., İş, G., Beton D. ve Çakırığlu, İ. 2008. Türkiye'deki Ramsar Alanları Değerlendirme Raporu. WWF Türkiye Doğal Hayatı Koruma Vakfı Yayını.

Toprak, R., Süheri, S. ve Acar, B. 2008 İklim-Tarımsal Kuraklık-Sulama ve Çevre Etkileşimi Yönünden Konya Havzası. Konya Kapalı Havzası Yeraltı Suyu ve Kuraklık Konferansı, Bildiri Kitabı: 67-76, 11-12 Eylül 2008, Konya,

Türkeş, M. and Erlat, E. 2005. Climatological Responses of Winter Preciptation in Turkey to Variability of the North Atlantic Oscillation During the Period 1930-2001. Theoretical and Applied Climatology, 81,45-69.

Türkeş, M., Akgündüz, S,A. ve Demirörs, Z. 2009. Palmer Kuraklık İndisin Göre İç Anadolu Bölgesi’nin Konya Bölümü'ndeki Kurak Dönemler ve Kuraklık Şiddeti. Coğrafi bilimler Dergisi, 7(2), 129-144.

Tunçez, S. ve Candan, E. 2008. Konya İli Çevre Durumu Raporu. Çevre ve Orman Bakanlığı Yayını, Konya.

TÜİK. 2010a. Nüfus İstatistikleri, http://tuikapp.tuik.gov.tr/adnksdagitapp/adnks.zul, 12.08.2010)

TÜIK. 2010b. Tarım İstatistikleri, ( ttp://www.tuik.gov.tr/VeriBilgi.do?tb_id=45\&ust_id=13, 08.07.2010) 
Şen, E. ve Başaran, N. 2008. Konya Kapalı Havzasının Sıcaklık ve Yağış Dizilerinin Trend Analizi. Konya Kapalı Havzası Yeraltı Suyu ve Kuraklık Konferansı, Bildiri Kitabı: 26-34, 11-12 Eylül 2008, Konya.

Ulu, Ü., 2009a. Türkiye Jeoloji Haritaları No:125, Karaman-M30, MTA Gen. Müd. Ankara.

Ulu, Ü., 2009b. Türkiye Jeoloji Haritaları No:126, Karaman-M31, MTA Gen. Müd. Ankara.

Üstün, A., Tusat, E. ve Yalvaç, S. 2010. Preliminary Results of Land Subsidence Monitoring Project in Konya Closed Basin Between 2006-2009 by Means of GNSS Observations. Natural Hazards and Earth System Sciences, doi:10.5194/nhess-10-1151-2010.

Zengin, M., Gökmen, F., Gezgin, S. 2008. Konya İlinde sulama suyu kalitesi, çölleşme ve alınması gereken önlemler. Konya Kapalı Havzası Yeraltı Suyu ve Kuraklık Konferansl, 11-12 Eylül 2008, Konya, 77-86. 